International Journal of Public Finance
E-ISSN: $2548-0499 \quad$ DOI: 10.30927/ijpf.327846
Vol./Cilt: 2 I Issue/Sayı: 1 | (2017), pp. 124-158
journal homepage: http://dergipark.gov.tr/ijpf

\title{
Veraset ve İntikal Vergisi'nde Revizyon Gerekliliği
}

\author{
The Need of Revision in the Inheritance and Succession Tax
}

\author{
Mehmet GÜNEŞ ${ }^{1}$
}

\section{ARTICLE INFO \\ Received: 11.07.2017 \\ Received in revised form: 10.09.2017 \\ Accepted: 14.09.2017 \\ Available online: \\ 15.09.2017 \\ JEL classification: $\mathrm{H} 2 \mathrm{O}, \mathrm{H} 27$}

\section{Keywords:}

Inheritance,

Gift and Tax

\begin{abstract}
A B S T R A C T
The aim of this study is to explain; Is to raise awareness, even a little bit, by emphasizing that the text of the law which has been practiced in the country for sixty years and which is devoted to all other provisions except death and taxes is far from commercial and social practices. The inheritance and transfer tax, which is a strategic joint venture of the wealthy and the poor, Its place and importance in tax revenues, the positive and benevolent reasons of its existence, and the fiscal and extraordinary purposes of taxation. Along with the impact of globalization, the change in spendingincome composition strongly suggests that the preponderance of the taxpayers has increased considerably. How is it that in economic life, economic position, wealth, and wealth are the most important pillars of the three-legged sheet when the economy, economy, and justice, the backbone of the financial life, the indicative of the financial power, and the fallacy are all important, if the economy cannot deny the role of labour, capital, entrepreneurship and natural resources. The fact that income redistribution, elimination of income-wealth inequalities and an important means of intervening in economic life depends on the principle of consolidation of the channels between the taxpayer and the administration as well as the collection of taxable income. In addition, as can be understood from the indicators, if the taxation capacity (political-financialeconomic-psychological) is very high and financial socio-economic aspect is taken into consideration; that the share in the budget can be increased without any reaction to the taxpayer. The data used were obtained from the official sites of the General Directorate of Budget and Financial Control and the Revenue Administration. Provisions containing practical and theoretical conflicts have been identified and proposed as solutions for the tax complexity index being too high. The conceptual framework of the study, the critique, and defense of its existence in the study has been explored historically, and the forms of practice have been explained. Limited work and financial legislation in the acute meaning of these issues, which have to be resolved and forgotten as soon as possible, have been studied.
\end{abstract}

\footnotetext{
${ }^{1}$ Gelir Uzmanı, Gelir İdaresi Başkanlığı \& Akdeniz Üniversitesi Maliye AD Yüksek Lisans Öğrencisi,
} mehmetgunes33@hotmail.com.tr 


\section{MAKALE Bílgisi}

Alındı: 11.07.2017

Gözden geçirilmiş

alındı: 10.09.2017

Kabul: 14.09.2017

Yayın: 15.09.2017

JEL Kodu:

$\mathrm{H} 2 \mathrm{O}, \mathrm{H} 27$

Anahtar Kelimeler:

Veraset, Hibe,

Vergi

\section{Ö ZET}

Bu çalışmanın amacl; memlekette altmış yıldır uygulanan ve ölüm ile vergi gibi iki hakikatten başka bütün hükümlerin eğreti durduğu kanun metninin, ticari ve sosyal teamüllerden uzak olduğunu vurgulayıp bir nebze de olsa farkındalık uyandırmaktır. Varsıl ve yoksul kesimin stratejik ortak paydası olan Veraset ve İntikal Vergisi'nin; vergi gelirleri içerisindeki yeri ve önemi, varlığının müspet ve menfi gerekçeleri, vergilerin fiskal ve ekstra fiskal amaçları ışı̆̆ında ele alınacaktır. Küreselleşmenin etkisiyle birlikte, harcamagelir kompozisyonlarındaki değişiklik, söz konusu verginin öneminin oldukça arttığını güçlü bir şekilde göstermektedir. İktisadi yaşamda nasıl ki, ekonomik olarak tam istihdama gidilen yolda emeğin, sermayenin, girişimciliğin ve doğal kaynakların kısacası her bir üretim faktörünün rolü yadsınamıyorsa, vergilemede kanunilik, iktisadilik ve adalet ekseninde, mali yaşamın bel kemiği, mali gücün göstergesi ve feraset edildiğinde üçayaklı sacın en önemli ayağından bir tanesi olan servetin de yeri önemlidir. Gelirin yeniden dağılımında, gelir-servet eşitsizliklerinin giderilmesinde ve iktisadi yaşama müdahalede önemli bir araç olabilmesi, vergiyi doğuran olaydan tahsilata kadar mükellef ile idare arasındaki kanalların sağlamlaştırılması esasına bağlıdır. Ayrıca göstergelerden de anlaşılacağı üzere vergileme kapasitesinin (siyasi-mali-iktisadi-psikolojik) hayli yüksek olduğu ve mali sosyolojik açıdan bakıldığında ise; bütçe içerisindeki payının, mükellefi nezdinde herhangi bir reaksiyonla karşılaşılmadan arttırılabileceği sonucunu doğurmuştur. Kullanılan veriler, Bütçe ve Mali Kontrol Genel Müdürlüğü ve Gelir İdaresi Başkanlığı resmi sitelerinden elde edilmiştir. Vergi karmaşıklık endeksinin çok yüksek olduğu kanunda pratik ve teorik ihtilaflar içeren hükümler tespit edilmiş olup çözüm önerileri sunulmuştur. Çalışmada verginin kavramsal çerçevesi, varlığının eleştirilmesi ve savunulması, tarihsel açıdan irdelenmiş ve uygulama şekilleri açıklanmıştır. Bir an önce çözüme kavuşturulması gereken ve unutulmuş olan bu hususlara ilişkin akademik anlamdaki kısıtlı çalışmalar ve mali mevzuat taraması yapılmıştır.

\section{Giriş}

Kamu gelirleri, kamu harcamaları, bütçe ve borçlanma gibi mali vakıa-ı mahsusaları inceleyen ve politika üreten maliye biliminin, daha teknik ifadeyle kamu kesiminin klasik anlamda üç temel fonksiyonu bulunmaktadır. R. Musgrave bu hususu; gelir dağılımında adalet, kaynak kullanımında etkinlik ve ekonomik istikrar olarak tasnif etmiştir. Devlet bu fonksiyonları yerine getirirken vergi anarşisinden veyahut kaosundan sıyrıldığında mükellef nezdinde de işlemler kolaylıkla algılanacaktır. Her kim pazarda satış yapıp para kazanırsa bunun iki akçesini versin, satamazsa hiç bir şey vermesin, kim bu kuralı bozarsa Tanrı da onun dinini ve dünyasını bozsun (Önal \& Temelli, 2012: 79). Bir zamanlar, Osman Gazi tarafından söylenmiş bu söz vergi sistemini bu kadar basit düzeye indirgemişken söz konusu kanundaki işlemlerin karmaşıklığı ve maliyetlerinin yüksekliği önemli ölçüde göze çarpmaktadır.

Kamu gelirleri bağlamında spesifik vergi sistemleri ile ilgili olarak kabul edilmelidir ki, hiçbir vergi sistemi ünlü ressam Salvador Dali'nin tabloları gibi mükemmel değildir. Hiç şüphesiz bu düşün yapısı, vergi sistemimiz için de geçerlidir. Bu sistem içerisinde mükellef odaklı hizmet anlayışı temelinde, Veraset ve İntikal 
Vergisi'nin vergilendirme sürecini; kolay, verimli, mali anestezi etkisi yüksek ve vergi tazyikinin düşük olduğu ayrıca mükellef ve idarenin mali külfetlerini azaltan yönerge oluşturmak bu çalışmanın amaçlarındandır.

Adolf Wagner, toplumların sosyal ilerleme isteklerinin kamu harcamalarını arttıracağını belirtmiştir. Bana, gelirlerini nasıl ve ne şekilde elde ettiğini söyle, sana senin harcamalarının ne olduğunu söyleyeyim. Bu açıdan, kamu gelirlerinin ve harcamalarının karşıııkı bağımlılığı maliye ilminin temel sorunudur (Falay, 1989: 4). Anlaşılan o ki; daha fazla gelir daha fazla sosyal, yatırım ve eğitim-sağıı (kalkınma carileri) harcamaları demektir.

îktisadi kaynakların verimli ve ekonomik kullanımı esaslı meseledir. Verimlilikteki mana, mali verimlilik; vergi hasılatı içinde payı yüksek olan vergi verimli iken, payı az olan vergi verimsizdir. İktisadi verimlilik (vergi işletim maliyetleri + idari maliyetler) ise, bir birim vergi hasılatını elde etmek için yapılacak harcamanın az olması yani verginin ucuza toplatılmasıdır (Erdem Vd. 2016: 159). Thomas Kaldor'un Türk Vergi Sistemi üzerine hazırlamış olduğu raporda, Türkiye'de ihtiyaçları karşılama açısından vergi gelirlerinin yetersiz olduğunu, servete dayanan vergiler konulmadıkça, gelir vergisinin adaletsizlikleri düzeltilemeyeceği ve geniş çaptaki kaçakçılığın önlenemeyeceğini yaklaşık 70 yıl evvel belirtmiştir.

Türk Vergi Sistemi'nde, kaybolmuş ve köhne bir vergi olarak görülen Veraset ve İntikal Vergisi ve diğer vergiler arasındaki hukuku ortaya seren, vergi retoriği açısından söz konusu kanun, sürüsünden ayrılmış bir koyun olarak değerlendirilebilir. Asıl mesele bu alanda, modern bir perspektifle küresel bilgi çağına yakışan yeni fikirler yeşertilmeli ki; devlet idaresinin vakar ve itibarını yücelten, vergi toplama ve mükelleflerin de vergi ödeme maliyetleri azaltılarak etkinlik sağlanabilmesidir. Bütün bunlar da teorik ve pratik hususların yanı sıra usul ve esaslara mutlak anlamda riayet edilerek ve mutlak bir özveri ile gerçekleştirilebilir.

Bilindiği üzere; servet vergilerinden olan Veraset ve İntikal Vergisi, vergiyi doğuran olaydan tahsilata kadar hemen hemen her yönüyle diğer vergi türlerinden oldukça farklıdır. Değişen sosyo-ekonomik parametrelere ve ticari teamüllere rağmen, her ne kadar yer yer değişiklikler yapılmış olsa da, esaslı olarak herhangi bir değişim gösteremeyen kanun metninin artık bir reforma ihtiyaç duyduğu apaçıktır. Özzeybek, 1976 yılında kaleme aldığı bu pek mühim mesele-i umumiye hakkında, yasanın yapımı sırasında unutulmuş veya gerekli açıklık getirilmemiş konular, toplumun ekonomik ve sosyal yapısındaki gelişmelere cevap verememiş ve bugünkü gereksemelerin gerisinde kaldığını belirtmiştir. $O$ günden bugüne kanun metni ve uygulaması ele alındığında herhangi esaslı bir dönüşümden bahsetmek pek de mümkün değildir.

Vergileme politikaları oluşturulurken; özellikle uygulamada birliğin sağlanmasında öz anlatımlı, birbirleriyle çelişmeyen hükümlerin olduğu, uzlaşmaya sevk eden mevzuat sistemi toplumdaki vergi yükünün dağılımı ve adil gelir dağılımının sağlanması açısından göz önünde bulundurulması gereken esaslı hususlardır. Kanunda sorun olarak görülen, ileride çözüm önerileri ve temenniler sunulacak alanlara kısaca bakıldığında; 
T.C. vatandaşının yurtdışındaki malvarlığını ve yurtdışından iktisap ettiği mal varlığının beyan sorununun, yine yurtdışında ödenen veraset ve intikal vergileri ödenip tevsik edilmesi şartıyla ödenecek vergiden değil matrahtan düşüleceği hususu mükerrer vergilemeyi önlemekten çok uzak bir uygulama olduğu, istisnaların kapsamının esnekliği, vergi tarifesindeki uzunluk ve yükseklik farklarının gözden geçirilmesi gerektiği, Emlak Vergisi Kanunu'na göre düşük olarak tespit edilen emlak vergi değerlerinin matrahın aşınmasına sebebiyet vermesi ve verginin tarhiyatındaki alakasızlık gibi hususlar söz konusu vergiye mali ve sosyal açıdan ket vurmaktadır. Medeni Kanun'da belirtilen mirasın reddedilmesi ve beyanname verme süreleri hükümlerin çelişmezliği hususuna ters düştüğü ve yeni mal rejimine göre miras taksimatının göz önünde bulundurulmaması önemli bir husus olarak görülmektedir.

Aslında bu kanuna karşı alakasızlık çok evvelden süregelmektedir. Şöyle ki; 797 sayılı Veraset ve İntikal Vergisi Kanunu yürürlükte iken; 18 Mart 1937 tarih ve 3557 sayılı resmi gazetede yayımlanan Veraset Ve Intikal vergisi tarhiyatında görülen alakasızlığa nihayet verilmesi konulu tamimde, “... varidat memurları iyice bilmelidirler ki, yalnı kendilerine gelen evrak ve beyannameleri tetkik ve muamelesini ifa etmekle vazifelerini ikmal etmiş sayılmazlar. Masası başından kımıldamayan, kanuni hak ve salahiyetlerini kullanmayan, kanuni vazifelerinden haberdar olmayan ve diğer eşhas ve müessesatın varidat idaresine karşı olan vazife ve mecburiyetlerini bilip takip ettirmeyen bir memur varidat teşkilatında çalışacak evsafı haiz addolunamaz. Maiyetlerinde bulunan varidat memurlarını sevk ve idare ve onların faaliyetlerine yakından alakadar olmağa mecbur bulunan varidat müdürü ve defterdarların dahi diğer hususlarda olduğu gibi veraset ve intikal vergisi tarhiyatının aldığı bu elim vaziyette de pek büyük hissei mes'uliyetleri bulunduğu muhakkaktır..." denilmektedir. Bu hükümler aslında bu kanunun pratikteki düşün altyapısına karine teşkil etmektedir.

Vergiye ilişkin ödeme sürelerinin çok uzun vadeye yayılması, tasdiknamenin bu süre sonunda verilebileceği çelişkisi ve işlem maliyetlerinin çok yüksek oluşu mükellef nezdinde reaksiyona yol açmaktadır. Modern anlamda maliyenin kurucusu olarak kabul edilen J.M. Keynes, 1936 yılında yayımlamış olduğu Genel Teori adlı yapıtında; devletin çukur kazdırıp doldurtma teorisi işlem maliyetlerinin yüksek oluşu yönüyle benzeşmekte olduğu söylenebilir. İşlem maliyetlerinden kasıt; malların fiili ve hukuki iktisabı için idare ve mükellef yönünden katlanılan emek ve zaman maliyetleri olarak tanımlanabilir. Mükellefin; Belediye, Noter, Mahkeme, Tapu, Banka, SGK gibi kurumlardan Maliye'ye belge ve bilgi getirmesi esnasında, vergi uzmanına başvurması ... gibi hususlar işlem maliyeti olarak örnek verilebilir. Kurumlar arası bilgi akışının zayıf olması, idari tetkik - tahkikatın güç olması ve teknolojik imkânlardan kısıtlı olarak yararlanılması işlemlerin gecikmesine yol açmaktadır. Cezai müeyyidelerinin zayıflığı, idare ve mükellef açısından vergisel davranışları olumsuz etkilemektedir. Insani bir müessese olan pişmanlık ve ıslah hükümlerinin mutlak olarak uygulanması gerekliliği ve engelli varislerin muafiyet kapsamına alınması önem arz etmektedir. Yine, çok önemli bir husus olan değerleme gününün değiştirilmesi vergiyi mutlak anlamda güçlü kılacaktır. 
íki başlı tarhiyatın idareye ve mükellefe yüklediği zahmetler ve kasa muhteviyatının tespitinde harcanan emek ve zaman israfı, küreselleşen dünyada teknoloji çağının gereklerine uyulmaması esaslı problemler olarak görülmektedir. Ayrıca Milli Piyango Genel Müdürlüğü tarafından düzenlenen çekilişlerden kazanılan ikramiyelerin vergi özel kanunu gereği kapsamı dışında kalması, şans oyunları ve çekilişlerden kazanılan ikramiyeler sabit oranlı vergi uygulaması yeniden gözden geçirilmesi gereken ve önem arz eden esaslı hususlardır.

Vergilendirme sürecinin tüm aşamalarında sorunlarla karşı karşıya kaldığımız söz konusu verginin rehabilite edilmesi kaçınılmazdır. Tespit edilen sorunlar, çözüm önerileri ve temenniler kümilatif olarak dikkate alındığında bütçe/vergi gelirleri arasında çok düşük bir paya sahip olan bu vergi önemli bir kamu geliri haline geleceği muhakkaktır.

Belirtmek gerekir ki; kaldırılması gündeme gelen 30/04/2008 tarihinde Veraset ve Intikal Vergisi Kanununun Yürürlükten Kaldırılması ve Gelir Vergisi Kanununda Değişiklik Yapılması Hakkında Kanun Tasarısı yasalaşamamıştır. Tasarı ile uyum maliyeti yüksek ve verimliliği çok düşük olan, tespiti mükellef ile idare arasında sıklıkla uyuşmazlıklara ve bu nedenle idare için zorluklara, maliyetlere ve zaman kaybına yol açan veraset yoluyla intikallerden alınan verginin kaldırılması, ivazsız suretle vaki intikallerin ise Gelir Vergisi içinde değerlendirilerek Gelir Vergisine tabi tutulması, böylece kayıtlı ekonomiye geçiş, vergilerin basitleştirilerek hem uygulamasının kolaylaştırılması hem de mükelleflerce kolaylıkla anlaşılması ve vergiye gönüllü uyumun artırıması yönünde önemli bir adım atılması amaçlanmaktadır (TBMM, 2008).

Devletin gelirin yeniden dağıtımı (redustribution of income) fonksiyonunun temelinde kaynaklar yatar. Bu kaynağın temelinde ise; vergilemede adalet ilkesi doğrultusunda ödeme gücünün unsurları olan gelir, servet ve harcamalar yatar. Küreselleşen dünyanın, artan rekabet sonucu vergi sofrasında gelir ve harcamalar üzerinden alınan vergileri sınırlandırdığı bir realitedir. Tam da bu hususta yeni kaynaklara ihtiyaç varken söz konusu husus gündeme gelmiştir.

Veraset ve Intikal Vergisi'ni kaldırmak yerine yeniden düzenlemek hem etkinliğini artırabilir hem de kaldırılmasıyla oluşacak olan boşluğu önleyebilir. Tasarıda dikkat çeken hususlardan biri de kayıtlı ekonomiye geçişin amaçlanmış olmasıdır (Kılıçarslan, 2011: 342).

Bilindiği üzere, ana akım iktisadi literatürde (kapitalist ekonomik sistem) ekonomi ilminin dünya ekonomisine pazarladığı ısmarlama tanımında, sınırsız insan ihtiyaçlarına kıt kaynaklarla cevap vermeye çalışan bir bilim dalı olarak görülmektedir. İşte temel olarak devlet-ekonomi organik ilişkisi, kaynakların kullanımında etkinliğin nasıl sağlanacağı noktasında ortaya çıkmaktadır. Devlet kanalıyla tahsis ilkesi temelinde, varsıl kesim ile yoksul kesim arasında gönül köprüsü söz konusu kaynaklarla kurulabilir. Bu kaynaklar temelde en önemli yeri işgal eden ve mali gücün de göstergeleri olan gelir, servet ve harcamalar üzerinden alınan vergilerdir. Her ne kadar kural ve kaidelerle uyumu sağlamak ve caydırıcılığı uygulamak gerekse de, gönüllü 
uyum ekseninde mükelleflerin ödevlerini yerine getirmesini sağlamak da çok önemli bir husustur.

Tahsis ilkesinin hâkim olduğu zekât gelirleri harcandığı yerler itibarıyla incelendiğinde, İslam maliye sisteminin toplumsal adalete, refaha verdiği önem ortaya çıkmaktadır. Çünkü maliye sistemi içerisinde önemli bir yer tutan zekât gelirlerinin fakirlere, miskinlere, köle azadına, borçlulara ve yolculara tahsis edildiği dikkate alındığında, toplumda refahın sağlanmasına atfedilen önem öne çıkmaktadır. Hatta bunun sağlanabilmesi için zekât gelirlerinin bu grup içerisinde yer alan herhangi birine örneğin sadece fakirlere harcanabileceği ifade edilmiştir (Ebu Yusuf, 1973: 139).

\section{Veraset ve İntikal Vergisi'nin Kavramsal Çerçevesi, Tarihçesi ve Uygulama Şekilleri}

Servet, Arapça kökenli bir kelime olup günümüzde farklı şekillerde tanımlanmaktadır. Gelirin harcanmayıp tasarruf edilen kısmı ile başlangıçta sahip olunan değerler toplamı servetin bileşenleri olduğunu söyleyebiliriz. Servet vergileri gelir ve servet dağııımını dengeleme amacına dayalı olarak salınırlar. Servet, marjinal tüketim ve tasarruf eğilimine, bu eğilimleri etkileyen başka faktörlere bağlı olarak, gelirin tasarruf edilen bölümünün bir uzantısı olarak oluşan, gelirin birikmiş şekli olarak tanımlanmaktadır (Akdoğan, 1999: 238). Yabancı dillerde ifade ettiği anlamlarına bakıldığında; İngilizcede property ve Fransızcada la fortune anlamlarına gelmektedir.

Veraset ve İntikal Vergisi, servet vergileri içerisinde yer alan önemli bir kamu geliridir. Önemlidir, çünkü varsıl ve yoksul kesimin stratejik ortak paydasıdır. Sosyal politika aracı olup gelir ve servet dağılımını dengeleme etkisi bulunmaktadır. Servet transferi sonucu alınan ve toplam vergi gelirleri içindeki payı yüzde bir oranına bile ulaşamayan literatürde "adı var kendi yok vergisi" olarak anılmaktadır (Bilici, 2014: 188). Veraset yoluyla ve ivazsız şekilde meydana gelen intikalleri vergilendirmektedir. Çeşitli vergileri içinde barındıran vergiler manzumesi olarak görülmektedir (Karakoç, 1990: 5).

7338 sayılı Veraset ve İntikal Vergisi Kanunu'nun (VIVK.) 2. maddesinde; "Bu kanunda kullanılan tabirlerin delalet ettiği manalar aşağıda gösterilmiştir:

a) "Şahıs" tabiri; hilafına sarahat olmadıkça hakiki ve hükmü şahısları;

b) "Mal" tabiri; mülkiyete mevzu olabilen menkul ve gayrimenkul şeylerle mameleke girebilen sair bütün hakları ve alacakları;

c) "Veraset" tabiri; miras vasiyet ve miras mukavelesi gibi ölüme bağlı tasarruflarl;

d) "ivazsı intikal" tabiri; hibe yoluyla veya herhangi bir tarzda olan ivazsız iktisapları; (Maddi ve manevi bir zarar mukabili verilen tazminatlar ivazsız sayılmaz.)

ifade eder" denilmektedir. 
Tarihi çok eskilere dayanan Veraset ve İntikal Vergisi'nin dünyada bilinen ilk uygulamalarına milattan önce VII. yüzyılda Mısır'da Ptolemyler döneminde ve milattan sonra I. yüzyılda Roma'da İmparator Agustus döneminde rastlanmaktadır (Yereli \& Uçar, 2014: 57).

Osmanlı Devleti'nde modern anlamda bir servet vergisi yoktu. Gayrimenkullerin veraset yoluyla intikallerinde intikal harcı, menkullerde ise tahrir harcı alınırdı. Ülkemizde ilk olarak 1926 yılında 797 sayılı Kanunla Aşar Vergisi'nin kaldırılmasından sonra ivazsız intikalleri de kapsayarak yürürlüğe girmiştir. Ancak ne bu vergi ne maliye tarihinin kara lekesi olan Varlık Vergisi ne de daha sonra ihdas edilen vergiler maalesef bütçenin üçte ikisini oluşturan Aşar Vergisi'nin yerini dolduramadı. 1926 yılında kabul edilen Veraset ve Intikal Vergisi'nin konusunun geniş olması ve istisna hükümlerinin dar tutulmuş olması şikâyetlere yol açmıştır. Bu arada Medeni Kanun'un yürürlüğe girmesi ve miras konusunda yeni bir hukuk düzeninin kurulması nedeniyle mevcut Veraset ve Intikal Vergisi Kanunu'nda 1931 yılında değişiklikler yapılmıştır (Saraçoğlu, 2009: 134).

Halen yürürlükte bulunan 15.06.1959 tarih ve 7338 sayılı Kanun, çıkarılmış olduğu dönemin ruhunu ve lafzını koruyarak bugüne kadar ulaşmıştır. Türkiye'de planlı ekonomi döneminde (1960-80) uygulanan vergi politikalarının, hazineye gelir sağlama gibi geleneksel fonksiyonlarının yanında, kaynak dağılımında etkinliği sağlama gibi ikinci bir görev üstlendiği gözlenmiştir (Takım, 2011: 160). Bu dönemde uygulanacak vergi politikalarının temel amacı makroekonomik politikalarla uyumlu bir şekilde büyüme ve istihdam politikalarının desteklenmesine, ekonomide kayıt dışılı̆ın azaltılmasına ve daha basit, adil ve geniş tabanlı bir vergi sisteminin oluşturulmasına katkıda bulunmaktır (Takım, 2011: 160). Dikkat edilirse, vergiler artık sadece kamu harcamalarının finansmanından öte ekstra fiskal amaçları da göz önünde bulundurularak alınmaya başlanmıştır. 1980'li yıllardan günümüze kadar, neoliberal akımın etkisiyle serveti vergilemenin ötesinde, devletin iktisadi yaşamdan uzak tutulması görüşünün temelinde mali vakıalara bakılmıştır. Günümüz dünyasında özellikle 1980 'li yıllardan itibaren hakim olan liberal ideoloji, özünde güçlü toplumsal kesimin çıkarlarının geliştirilmesine dayanan vergileme politikasının her noktasına nüfuz eden akımdır (Karabacak, 2004: 170).

Vergi Usul Kanunu'nun 12., 149., 150. madde hükümleri ile ilgili olarak alakasız davranan sorumlulara ise; yine cezai müeyyide olarak Vergi Usul Kanunu'nun mükerrer 355. madde hükümlerinin uygulanacağı tabidir. Yönetimin, verginin konusuna giren intikalleri kendiliğinden tespiti ise; genellikle, vukuat ve intikal olaylarında, işlemden duyumu olan kişi ve kuruluşların yazılı bildirimleri üzerine ve çoğu kez uzun bir zaman süreci içerisinde gerçekleştirebilmektedir (Yılmaz, 1997: 37). Uygulama şekillerine bakıldığında ise servetlerin vergilendirilmesinde çeşitli uygulamalar bulunduğu görülmektedir. Şöyle ki;

Tereke Vergisi, murisin terekesi henüz mirasçılara intikal etmeden, mirasçıların muris ile hısımlık dereceleri, kişisel ve ailevi durumları göz önünde bulundurulmadan terekenin tamamı üzerinden genellikle artan oranlı ve objektif nitelikli olarak alınan bir servet vergisi türüdür. 
Miras Payı Vergisi, ülkemizde uygulanan ve en yaygın olan sitemdir. Başlangıçta civar hısımlarından alınan vergi ve müstakim hat(usul-füru) muaf tutulmuştur. Devletin fonksiyonlarının genişlemesi sonucu kan hısımların eş ve çocukların da vergi ödemelerini zaruri kılmıştır.

Intikal Vergisi, sağlar arası ivazsız intikalleri kapsamaktadır.

Karma Sistem (Miras Vergisi), melez bir sistemdir. Fransa ve Almanya kullanmış sonra sadece Miras Payına geçmiş, İngiltere'de kısmen uygulanmış olup i̇talya'da uygulanan bir sistemdir.

Ölü El Vergisi, Tüzel kişiler de gerçek kişilerin tabi olduğu hükümlere tabi olduğu sistemdir. Amaç haksız rekabeti önlemek olup Federal Almanya'da uygulanmıştır (Karakoç, 1990: 5-30).

\section{Verginin Konusu, Mükellefi, Vergiyi Doğuran Olay, Mükellefiyetin Başlangıcı, Zamanaşımı ve Gecikme Faizi}

Toplumsal bir varlık olan bireyin kaçamayacağı vergi ve ölüm gibi mali-sosyolojik iki önemli olayın resmedildiği Veraset ve İntikal Vergisi'nde, üzerine vergi konulan şey, veraset yoluyla veya ivazsız bir şekilde intikal eden mallardır. Bu hususlar doğrultusunda temelde iki ayrı mali olayı kapsayan Veraset ve Intikal Vergisi, vergilemede adalet, iktisadilik ve açıklık ilkeleri benimsenerek teoride ve uygulamada temelleri sağlamlaştırılması gereken bir vergidir. Bu yönüyle idare ve mükellef tarafından maruz kalınan kaos, en azından minimize edilmiş olup kaotik uygulamalar ortadan kaldırılmış olur. Medeniyet geliştikçe mali olayların da çeşitlendiğinin yanı sıra modern uygulamalarda dahi, mali konuların içinden çıkılmaz bir hal aldığı söylenebilir. Vergi karmaşıklığı modern vergi sistemlerinin kaçınılmaz sonu olmuştur (Karabacak, 2013: 15-30). Şöyle ki;

ViVK. 1. maddesinde: "Türkiye Cumhuriyeti tabiyetinde bulunan şahıslara ait mallar(T.C. Vatandaşlarının yurtiçinde ve yurtdışında bulunun malları) ile Türkiye'de bulunan malların veraset tarikiyle veya her hangi bir suretle olursa olsun ivazsı bir tarzda bir şahıstan diğer şahsa intikali Veraset ve Intikal Vergisi'ne tabidir. Bu vergi, Türk tabiiyetinde bulunan şahısların ecnebi memleketlerde aynı yollardan iktisap edecekleri mallara da şamildir. Türkiye Cumhuriyeti tabiiyetindeki bir şahsın Türkiye hudutları dışında bulunan malını veraset tarikiyle veya sair suretle ivazsız bir tarzda iktisap eden ve Türkiye'de ikametgahı olmayan ecnebi şahıs bu vergi ile mükellef tutulmaz" hükmü yer almaktadır.

Şahsilik ve mülkilik ilkelerinin birlikte uygulandığı bu hükümde Türkiye Cumhuriyeti tabiiyetinde bulunan şahıslara ait yurtdışındaki malların değerlemesi tespiti ve beyanı konusunda bir açık alan söz konusudur. Yurtdışı teşkilatlarımızın bu konudaki idari tahkikatlarının yurtdışındaki matrah unsurlarının tespiti açısından önemi ve rolü büyüktür. Verginin konusu, şahsilik ve mülkilik ilkeleri kapsamında aşağıdaki tabloda yer almaktadır. 
Tablo 1: Şahsilik ve Mülkilik Illkesine Göre Verginin Konusu Mallar

\begin{tabular}{|c|c|c|c|c|}
\hline \multirow{2}{*}{$\begin{array}{l}\text { Malın Ait } \\
\text { Olduğu Kişi }\end{array}$} & \multirow{2}{*}{$\begin{array}{l}\text { Malın Nerede } \\
\text { Olduğu }\end{array}$} & \multicolumn{2}{|c|}{ Malın İntikal Ettiği Kişinin } & \multirow{2}{*}{$\begin{array}{c}\begin{array}{c}\text { Vergi } \\
\text { Konusuna }\end{array} \\
\text { Girer/Girmez }\end{array}$} \\
\hline & & Vatandaşlığı & İkametgâh & \\
\hline \multirow{5}{*}{ Türk Vatandaşı } & \multirow{2}{*}{ Türkiye } & Türk Vatandaşı & \multirow{3}{*}{$\begin{array}{l}\text { Türkiye İçi } \\
\text { veya Dışı }\end{array}$} & \multirow{4}{*}{ Girer } \\
\hline & & Yabancı & & \\
\hline & \multirow{3}{*}{ Türkiye Dışı } & Türk Vatandaşı & & \\
\hline & & Yahon & Türkiye İçi & \\
\hline & & tavarict & Türkiye Dışı & Girmez \\
\hline \multirow{4}{*}{ Yabancı } & \multirow{2}{*}{ Türkiye } & Türk Vatandaşı & \multirow{4}{*}{$\begin{array}{l}\text { Türkiye İçi } \\
\text { veya Dışı }\end{array}$} & \multirow{3}{*}{ Girer } \\
\hline & & Yabancı & & \\
\hline & \multirow{2}{*}{ Türkiye Dışı } & Türk Vatandaşı & & \\
\hline & & Yabancl & & Girmez \\
\hline
\end{tabular}

Kaynak: Doğan ŞENYüZ (2007). Türk Vergi Sistemi Dersleri, Ekin Kitabevi, Bursa, s.298.

Madde hükmündeki mefhumun muhalifinden anlaşılan odur ki; Veraset ve Intikal Vergisi'nin kapsamı dışında bırakılmış olan tek intikal, yurtdışındaki Türk vatandaşlarına veya yabancı şahıslara ait bir malın, Türkiye'de ikametgahı olmayan yabancı bir şahsa intikalidir.

Demek ki, bir malın bu verginin mevzuu dışında kalması için;

a) Malın Türkiye dışında bir ülkede bulunması,

b) Ölümün vuku bulduğu tarihte, Türkiye'de ikamet eden Türk tabiiyetinde bulunmayan (Ecnebi) bir şahsa ait olması,

c) Bu malların ikametgah ve meskeni Türkiye'de olsa bile Türk tabiiyetinde olmayan(Ecnebi) şahıslara intikal etmiş olması gerekmektedir (Özzeybek, 1976: 32).

ViVK. 5. maddesinde: "Veraset Ve intikal Vergisi'nin mükellefi veraset tarikiyle veya ivazsız bir tarzda mal iktisab eden şahıstır" hükmü yer almaktadır. Mükellefin konuya temas ettiği hususta da idari işlemin sebep unsuru olan vergiyi doğuran olay vuku bulur. Vergi Usul Kanunu'nun 19. maddesinde, vergiyi doğuran olay: “Vergi alacağı vergi kanunlarının vergiyi bağladıkları olayın vukuu veya hukuki durumun tekemmülü ile doğar. Vergi alacağı mükellef bakımından vergi borcunu teşkil eder" olarak ifade edilmiştir. Ayrıca her vergi kanununda bu husus farklı şekilde gerçekleşmektedir. Kısacası; konusu, mükellefi, matrahı ve oranı kanunda belirtilmiş olan mücerret(soyut) bir verginin, mükellef bakımından muayyen ve müşahhas(ferdi) bir borç haline gelmesi için bir sebebe intiyaç vardır. İşte bu sebep, vergiyi doğuran olay, yani vergi borcunun doğumuna sebep olan vakıadır (Karakoç, 1990: 83). Mükellefiyetin başlaması için de, vergiyi doğuran olayın gerçekleşmesi gerekmektedir. Veraset tariki ile vuku bulan intikallerde vergiyi doğuran olay, ölüm olayının 
gerçekleşmesi veya kişinin gaipliğine karar verilmesidir. İvazsız intikallerde ise, vergiyi doğuran olay, özellikle hukuki bir işlemin olgunlaşması ile gerçekleşmektedir (Şafak \& Yurtsever 2015: 32).

Mali yazında her ne kadar vergiyi doğuran olayın, ölüm hadisesi mi ya da malların intikallerinin gerçekleşmesi mi hususu tartışmalı olsa da bu hususta özel kanun ezber bozarak, zamanaşımın başlangıcında vergiyi doğuran olayı değil, mükellefiyetin başlangıcını baz almıştır. Bu hükümle iltisaklı olarak, Vergi Usul Kanunu 114. maddesinde: "Vergi alacağının doğduğu takvim yılını takip eden yılın başından başlayarak beş yıl içinde tarh ve mükellefe tebliğ edilmeyen vergiler zamanaşımına uğrar ..." hükmüme bakıldığında, tarh zamanaşımı vergiyi doğuran olaya bağlı olmasına rağmen, veraset ve intikal vergisinde mükellefiyetin başlamasına bağlanmış olup, verilen beyannamede gösterilmeyen mallar ile beyanname verilmeyen hallerde intikal eden malların idarece tespit olunduğu tarihte başlayacağı belirtilmektedir. Bu hüküm ile idarenin bilgisi dışında kalan mallar bakımından adeta sınırsız bir zamanaşımı öngörülmektedir. Tarhiyat yapıldıktan sonra, ödenecek hale gelen verginin tahsili ise, 6183 sayılı AATUHK'nın "tahsil zamanaşımı” ile ilgili hükümlerine göre işlem görecektir (Aydın, 2009: 197).

Veraset ve İntikal Vergisi Kanunu'na göre, vergi mükellefiyeti ne ölüm tarihinde ne de iktisap tarihinde başlatılmaktadır.

VIVK 20. maddesinde: "Veraset ve Intikal Vergisi mükellefiyeti:

a) Beyanname verildiği takdirde, beyannamede gösterilen mallar için beyanname tarihinde;

b) Verilen beyannamede gösterilmeyen mallar ile beyanname verilmeyen hallerde intikal eden malların idarece tespit olunduğu tarihte;

c) Terekenin tahriri, defter tutma veya resmi tasfiye hallerinde mahkemece bu muamelelerin ikmal edildiği tarihte; başlar" hükmü yer almaktadır.

Belirtmek gerekir ki, zamanaşımı mefhumu psikolojik bir husustur. Bu husus da mükellefi tedirgin edip ödevlerini yerine getirmede olumsuz anlamda etkiliyor. Tarh zamanaşımının sınırsız olması idari açıdan keyfiliğe yol açtığından bir süreye bağlanmalıdır. Veraset ve İntikal Vergisi'nde zamanaşımı süresinin başlangıcı bakımından getirilen ve Vergi Usul Kanunu'nun vergiyi doğuran olay ilkesine uymayan bu hükmün vergi idaresinde etkinliğin sağlanmasından sonra kaldırılması gerekmektedir (Karakoç 1990: 86).

Demek ki, Veraset ve İntikal Vergisi'nde zamanaşımının başlangıcı, ölüm veya ivazsız surette iktisap tarihi değil; beyanname ile bildirilen mallar için beyannamenin verildiği, beyan edilmeyen mallar için bu malların idarece tespit edildiği tarihi takip eden yılın birinci gününden başlar. İntikal tarihinden çok uzun bir süre sonra tespit olunan mallar için herhangi bir ceza uygulaması söz konusu olmadığı için, bu durum iyi niyetli mükellefleri cezalandırma olarak görülmektedir. Ancak, tahsil ve ceza zamanaşımı genel hükümlere tabidir (Özzeybek, 1976: 169).

Bu hususta yanlış olan iki şeyden bir tanesi mükellefin gerek sorumluluğunu bilmemesinden ya da yüksek vergi ödeyeceğine ilişkin korkularından kaynaklı bir ödev 
ihlali iken, diğeri ise idarenin tahkikatının noksanlığıdır. Örneğin, 1980 yılı ocak ayında kendilerine veraset yoluyla aynı nitelikte ve aynı değerde mal intikal eden Bay $(A)$ ve (B)' den Bay (A) beyannamesini süresi içinde vergi dairesine vermiş ve hesaplanan toplam 300 TL vergiyi ödemiştir. Aradan geçen 28 yıl sonra her iki kişiye de intikal eden servetin değeri yaklaşık 2800 kat artmıştır. Dolayısıyla Bay (A)'nın ödediği verginin alım gücü değeri de yaklaşık 2800 kat artmış olmaktadır. Bay (B) ise beyannameyi 2008 yılı ocak ayı içinde vergi dairesine vererek o da aynı değerler yani intikal eden servetin 28 yı önceki değerleri üzerinden ve aynı vergi tarifesi esas alınarak hesaplanan sadece 300 TL vergiyi ödemiştir. İdarenin mükellefiyeti zamanında tespit etmemesi nedeniyle ihmal veya kusuru da bulunmaktadır. Buradan hareketle, mükellefiyetin geç tespit edilmesi nedeniyle vergi alacağının gecikmeli olarak tahsil edilmiş olması dolayısıyla ortaya çıkacak paranın zaman değeri kaybının telafi edilmesine yönelik olarak gecikme faizi uygulaması yerinde olacaktır.

Vergi Usul Kanunu'nun 112/ 3. fıkrasında da belirtildiği üzere tahakkukun gecikmesi nedeniyle uygulanan gecikme faizi hakkında; "Vergi mahkemesinde dava açma dolayısıyla (4444 sayılı Kanunun 13/C-2 maddesiyle değişen ibare) 2577 sayılı Idarî Yargılama Usulü Kanununun 27 nci maddesinin 3 numaralı fıkrası (*) gereğince tahsili durdurulan vergilerden taksit süreleri geçmiş olanlar, vergi mahkemesi kararına göre hesaplanan vergiye ait ihbarnamenin tebliği tarihinden itibaren bir ay içinde ödenir. Ayrıca ikmalen, re'sen veya idarece yapılan tarhiyatlarda:

a) Dava konusu yapılmaksızın kesinleşen vergilere, kendi vergi kanunlarında belirtilen ve tarhiyatın ilgili bulunduğu döneme ilişkin normal vade tarihinden itibaren, son yapılan tarhiyatın tahakkuk tarihine kadar;

b) Dava konusu yapılan vergilerin ödeme yapılmamış kısmına, kendi vergi kanunlarında belirtilen ve tarhiyatın ilgili bulunduğu döneme ilişkin normal vade tarihinden itibaren, yargı organı kararının tebliğ tarihine kadar;

Geçen süreler için 6183 sayılı Kanuna göre tespit edilen gecikme zammı oranında gecikme faizi uygulanır. Gecikme faizi de aynı süre içinde ödenir. Gecikme faizinin hesaplanmasında ay kesirleri nazara alınmaz.

Uzlaşılan vergilerde gecikme faizi; uzlaşılan vergi miktarına, (a) fıkrasında belirtilen tarihten itibaren uzlaşma tutanağının imzalandığı tarihe kadar geçen süre için uygulanır" hükmü yer almaktadır.

Vergi Daireleri İşlem Yönergesi'nde: “Veraset ve intikal vergisi beyannamelerinin 213 sayılı Vergi Usul Kanununun 342. maddesinde açıklanan ek süreler içerisinde verilmiş olması halinde, (birinci ek süre ile ikinci ek süre arasında verilen beyannameler dahil) vergi ziyaı olmamış sayılır. Dolayısıyla söz konusu beyannameler kanuni sürede verilmiş sayıldıklarından, bu süre içerisinde verilen beyannameler üzerine yapılan tarhiyatlar için gecikme faizi uygulanmaz.

Mükelleflerin kanuni sürede veya 342. maddede belirtilen süre içerisinde verdikleri veraset ve intikal vergisi beyannamesine göre, mükellef beyanı üzerine yapılan ilk tarhiyattan sonra re'sen, ikmalen veya idarece tarhiyat yapılmış olması halinde, tarh olunan vergiye ilk tarhiyatın vade tarihinden, ikmalen, re'sen veya idarece yapılan tarhiyatın tahakkuk tarihine kadar geçen süre için taksit zamanları dikkate 
alınmak suretiyle gecikme faizi hesaplanır. Gecikme faizi ödeme süresi geçmiş olan taksitler için uygulanır. Ödeme süresi geçmemiş olan taksitler için gecikme faizi uygulanması mümkün değildir.

Vergi Usul Kanununun 342. maddesinin ikinci fıkrası hükmü uyarınca, veraset ve intikal vergisi mükelleflerinin idarece beyana çăgrılmaları üzerine kendilerine verilen 15 günlük ikinci ek süre içerisinde beyanname vermeyerek bu süreden sonra söz konusu beyannamelerini vermeleri halinde, mükelleflerin beyanı üzerinden yapılan tarhiyat için gecikme faizi alınır" yer verilmiştir. Demek ki, mükellefin beyan etmiş olduğu vergiye uygulanacak gecikme faizinin başlangıç tarihi, idarece yapılan beyana çağrı tarihinden sonraki 15 günlük ikinci ek sürenin sonu olacaktır. Ayrıca, takdir komisyonu kararına göre matrah farkı çıkması halinde, yapılacak tarhiyata da uygulanacak gecikme faizinin başlangıç tarihi, yine idarece yapılan beyana çağrı tarihinden sonraki 15 günlük ikinci ek sürenin sonu olacaktır. Gecikme faizi, beyana çağrı yapılması ve matrah farkının oluştuğu durumda hesaplanmaktadır. Geç beyan durumunda, idare tarafından yargı kararlarını da göz önünde bulundurularak vergi ziyaı cezasına girmeden usulsüzlük cezası ile yetinilmektedir. Mükellefler tarafından bildirilmemiş ya da daha sonra bildirilen mallar için vergi ziyaından ve gecikme faizinden beyana çağrı olmadan bahsedilemez; çünkü mükellefiyet, beyannamenin verildiği zaman diliminde gerçekleşmektedir.

Yukarıdaki örnekte, mükellefin 1980 yılında ödemesi gereken 300 TL tutarındaki vergiye 2008 yılına kadar yürürlükteki gecikme faizi üzerinden faiz işletilerek bugünkü değerinin korunması sağlanmış olacaktır (Şafak \& Yurtsever, 2015: 32). Diğer taraftan mükellef ödevlerini zamanında yerine getirmesine rağmen nihai tarhiyat için takdir komisyonunda geçen süreler dikkate alındığında gecikme faizinden kaçınılmaz olarak ödediğini göz önüne alırsak mükellefi ödevlerinden uzaklaştıran bir husus olarak da değerlendirilmesi gerekir.

Asıl meselelerden bir tanesi de, asimetrik bilginin ya da bilgi kirliliğinin ortadan kaldırılması gerekmektedir. Bu kapsamda devlet, vatandaşlarına bu yöndeki sorumluluklarını öğretecek ve vatandaşlarını bilgilendirecek çeşitli proje ve politikalar geliştirmelidir. Ölüm vakası sonrasında mirasçıların hangi yükümlülükleri ve hakları olduğu yasalarda açık ve anlaşılır biçimde belirtilmelidir. Kamu spotları ve ilanlar gibi görsel ve yazılı medya etkin bir şekilde kullanılmalıdır. Bu konuda yetkili en üst kamu kurumundan muhtarlıklar seviyesine kadar bilgilendirme çalışmaları gerçekleştirilmelidir (Öz ve diğerleri, 2017: 43).

\section{Muafiyet, İstisna, Matrah ve Tarhiyat}

Muafiyet, aslında vergi mükellefi olması gereken bir gerçek veya tüzel kişinin, kanunun açık hükmüne uyularak vergi dışı bırakılmasıdır (Karakoç: 1990: 68). Veraset ve İntikal Vergisi Kanunu'nda; kamusal muafiyetler, kamu yararı amacı güden teşekküllere ait muafiyetler ve diplomatik muafiyetler olmak üzere üçe ayrılmaktadır.

ViVK. 3. maddesinde: "Aşağıda yazılı şahıslar Veraset ve intikal Vergisinden muaftır: 
a) Amme idareleri, emekli ve yardım sandıkları, sosyal sigorta kurumları, umumi menfaate hadim cemiyetler, siyasi partiler ve bunlara ait olan veya bunları aralarında kurdukları teşekküllerden Kurumlar Vergisine tabi olmayanlar;

b) Yukarıdaki fıkrada sayılanlar dışında kalan hükmi şahıslara ait olup umumun istifadesi için ilim, araştırma kültür, sanat, sıhhat, eğitim, din, hayır, imar, spor gibi maksatlarla kurulan teşekküller;

c) Yabancı Devletlerin Türkiye'de bulunan elçi, maslahatgüzar ve konsolosları (Fahri konsoloslar hariç) ile elçilik ve konsolosluklara mensup olan ve o Devletin tabiyetinde bulunan memurları ve Türkiye'de resmi bir vazifeye memur edilenler ile bu sayılanların aileleri efradı (Mütekabiliyet şartiyle) (Türk tabiiyetinde bulunan şahıslardan veraset tarikiyle veya sair suretle mal iktisabedenlerle yukarda sayılanların dışında kalıp da Türkiye'de ikamet eden şahısların Türkiye'de bulunan mallarını veraset tarikiyle veya sair suretle iktisabedenler hariç)" hükmüne yer verilmiştir.

Engelli varislerin de sahip oldukları servet değerlerinin gelir getirme kabiliyetleri göz önünde bulundurularak muafiyet kapsamında vergi dışı bırakılması vergilemenin sosyal fonksiyonunu pekiştirecektir.

İstisna, vergi kanunlarına göre vergilendirilmesi gereken bir konunun kısmen veya tamamen, sürekli veya geçici olarak vergi dışı bırakılması durumudur. Görüldüğü gibi verginin istisnasından söz edebilmek için öncelikle konunun, vergi kapsamı içerisine alınmış olması gerekmektedir (Aydın, 2009: 61). 5018 sayılı Kamu Mali Yönetim Kontrol Kanunu'na göre; muafiyet, istisna ve indirim dolayısıyla vazgeçilen vergi gelirleri maliye yazınında vergi harcaması olarak anılır (Bilici, 2014: 55).

Hiç şüphesiz ekonomik gelişmişliğin temelinde, güçlü bir sermaye birikimi ve tasarruflar yatar. Her ne kadar sosyal saiklerle de yer verilmiş olsa mevcut sermaye birikimi göz önünde bulundurulduğunda, istisna hadlerinin yüksek olması optimal vergilemeye aykırı bir hususu teşkil etmektedir. Varislerin, beyanname vermemesi halinde bu durumun saptanma olasılığının düşük olması itibariyle eş ve çocuklar dışındaki yakın akrabaların istisnadan yararlanamıyor olması bir sorun olarak dikkat çekmektedir (Gönül, 2008: 104).

ViVK. 4. maddesinde: "Aşağıda gösterilen intikaller Veraset ve intikal Vergisinden müstesnadır:

a) Veraset tariki ile intikal eden ev eşyası ile murise ait zat eşyası ve aile hatırası olarak muhafaza edilen tablo, kılıç, madalya gibi eşya;

b) Değerleri 10 uncu maddeye göre belirlenen menkul ve gayrimenkul mallardan evlatlıklar da dahil olmak üzere füruğ ve eşten her birine isabet eden miras hisselerinin 176.600 TL (füruğ bulunmaması halinde eşe isabet eden miras hissesinin 353.417 TL);

c) Örf ve adete göre verilmesi mutat bulunan hediye, cihaz, yüzgörümlüğü ve drahomalar -Türk Dil Kurumu Genel Türkçe Sözlügüne göre drahoma: Hıristiyan ve Musevilerde gelinin damada verdiği para veya maldır-(Gayrimenkuller hariç);

c) Bilumum sadakalar;

d) ivazsız suretle vaki intikallerin $4.068 T L$, 
e) Para ve mal üzerine düzenlenen yarışma ve çekilişler ile 14/3/2007 tarihli ve 5602 sayılı Şans Oyunları Hasılatından Alınan Vergi, Fon ve Payların Düzenlenmesi Hakkında Kanunda tanımlanan şans oyunlarında kazanılan ikramiyelerin 4.068 TL, ..." hükmü yer almaktadır.

Halk arasında yaygın deyişle çifte kavrulmuş lokum olan evlatlık istisna kapsamında iken; anne, baba, kardeş, amca, hala, teyze ve dayı gibi kan hısımlarının aleyhine bir durumun söz konusu olduğunu görmekteyiz. Hiç olmazsa anne, baba ve kardeşin istisna kapsamına alınması kanunu sosyal yönden daha güçlü kılacaktır.

Vergi matrahının tayininde, gayrimenkullerin emlak vergisine esas olan değerle değerlenmesi temelinde gerçek bedelden uzak olması istisna hadleri altında kalmasına neden olmaktadır. Taşınmaz değerlemelerinin gerçekçi bir şekilde yapılamamasından vergisel, ekonomik ve sosyolojik problemler ortaya çıkmaktadır. Geriye dönük 1983 yılında ihdas edilen 1319 sayılı Emlak Vergisi Kanunu'nun 29. madde hükmü, bağlı tebliğ ve tüzük uyarınca emlak vergi değerlerinin belediyeler tarafından verilememesi zaten çok yoğun olan Takdir Komisyonlarının iş yüklerini arttırmaktadır. Tarhiyat ilk ve son tarhiyat(tamamlayııı) olmak üzere iki şekilde yapılmaktadır. Bu husus vergi karmaşıklığına neden olmaktadır.

7338 sayılı ViVK.'nın yürürlüğe girdiği 1959 yılında ilk ve nihai tarhiyat ayrımı bulunmuyordu. Verginin ilk uygulamasında, mükellefin beyanı üzerine idare intikal eden mallarla ilgili ayrı bir tahkikat yapmakta ve daha sonra buna bağlı olarak vergiyi tarh etmekteydi. Mükellefin beyanından sonra gerçekleştirilen tahkikatın çok uzun sürmesi ve vergi tahsilatlarının buna bağlı olarak gecikmesi üzerine, 1970 yılında ilk ve nihai tarhiyat ayrımı yapılmış ve mükellefin beyanı üzerine yapılacak olan ilk tarhiyat için daha basit ve uygulanabilir değerleme ölçüleri tercih edilmiştir. Ödenmesi gereken vergiye esas olacak matrahın tespit edildiği nihai tarhiyat aşamasında ise intikal eden malların gerçek değerini kavramaya yönelik, öncekine kıyasla biraz daha karışık ve nitelikli değerleme ölçüleri benimsenmiştir. Yapılan değişiklikle, ViVK'nın 10'uncu maddesindeki ölçüler esas alınarak yapılan ilk tarhiyatın, intikal eden malların VUK'a göre bulunacak değerlerine göre idare tarafından ikmal edilmesi gerektiği hükme bağlanmıştır (Özbek, 2017: 8).

ViVK. 10. maddesinde: "Veraset ve intikal Vergisinin matrahı, intikal eden malların Vergi Usul Kanununa göre bulunan değerleridir. ...

b) Gayrimenkuller ticari işletmeye dahil olsun veya olmasın Emlak Vergisine esas olan değerle değerlenir.

c) Menkul mallar ve gemiler rayiç bedelle değerlenir ..."

Vergi Usul Kanunu'nun 298. maddesinde yer alan "Bu bölümde yazılı emsal bedelleri ile alacak ve borçların değerleri 72. maddede yazılı Takdir Komisyonu tarafından tespit edilir" hükmü nedeniyle, takdir komisyonları tarafından yapılacak değerlemeyi beklemeden mükellefler tarafından beyan edilecek değerler üzerinden ilk tarhiyatı yaparak verginin tahsilatını hızlandırmaktır. İdare 10. maddedeki esaslara göre beyan edilen değerler üzerinden vergiyi beyannamenin verildiği tarihten itibaren en geç on beş gün içinde tarh eder. Tarh edilen vergiler intikal eden malların Vergi Usul Kanunu'na göre bulunacak değerlerine göre ikmal edilir. Bu hususta da kesilen vergi 
ziyaı cezası ve hesaplanan gecikme faizi ödettirilmektedir. Bu şekilde hem mükellef hem de takdir komisyonları marifetiyle yapılan işlemler sadeleştirilmelidir. Çıkan matrah farkına uygulanan cezai müeyyide mükellefi kayıtdışılığa itmektedir. Emek, zaman ve örtük maliyetlerde artışa neden olduğundan vergi karmaşıklığına son verip tek seferde tarhiyat bitirilmelidir. Ayrıca turizm bölgeleri için arazilerin getirileri göz önünde bulundurulup özel değerleme kurulları oluşturulabilir. Vergi İnceleme ve Denetim iç̧ Genelgesi, Vergi Incelemelerinde Uyulacak Usul ve Esaslar Hakkında Yönetmelik ve 178 sayılı KHK hükümleri uyarınca; Veraset ve İntikal Vergisi mükelleflerinden, iktisap ettikleri ticari servete dahil işletmelerin murisin hissesine isabet eden aktif tutarı 13 milyonu aşan mükelleflerle ilgili inceleme talepleri Vergi Denetim Kurulu (b), (c) ve (ç) Grup Başkanlıklarınca, 13 milyon TL kadar olan inceleme talepleri (a) Grup Başkanlığınca ve 3 milyona kadar mükelleflerle ilgili inceleme talepleri takdir komisyonları vasıtasıyla gerçekleştirilmektedir. Her ne kadar bu hükümler yer alsa da başta matrahın aşınmasına yol açan vergi değeri ve diğer menfi hususlar nedeniyle uygulamada pek de rastlanan mali olaylar değildir.

\section{Teklif Mahalli, Beyannamenin Verileceği Yer, Beyanname Verilme Müddeti, Pişmanlık ve Islah, Tenzil Olunabilecek Borçlar ve Masraflar, Değerleme Günü ve Nispet}

Teklif mahalli düzenlemesinin amacı aslında idarelerin yetki sorununu çözmektir. Vergi Usul Kanunu'nun 4. maddesinde; “Vergi dairesi mükellefi tesbit eden, vergi tarh eden, tahakkuk ettiren ve tahsil eden dairedir" denilmektedir.

ViVK. 6. maddesinde: "Veraset ve intikal Vergisi,

a) Veraset tarikiyle(gaiplik de ölüm karinesidir) vaki intikallerde ölen kimsenin, diğer suretle vukua gelen intikallerde tasarrufu yapan şahsın(malını hibe edenin) ikametgâhının, hükmi şahıslarda ve diğer teşekküllerde merkezlerinin bulunduğu;

b) Muris veya tasarrufu yapan şahsın bu ikametgâhı yabancı bir memlekette ise Türkiye'deki son ikametgâhının bulunduğu;

c) Muris veya tasarrufu yapan şahıs Türkiye'de hiç ikamet etmemiş veya son ikametgâhı tespit olunamamış ise Maliye Vekaletinin tayin edeceği; yer vergi dairesi tarafından tarh olunur." denilmektedir. Belirtilen hükümlerle iltisaklı olarak;

ViVK. 8. maddesinde: "Beyannameler, 6. maddenin (a) ve (b) fikralarına giren hallerde vergi dairelerine, (c) fıkrasına giren hallerde Maliye Vekaletine verilir. Yabancı memleketlerde bulunan mükellefler beyannamelerini Türkiye konsolosluklarına verirler. Beyannamenin her mükellef için ayrı ayrı veya müştereken verilmesi caizdir " hükmüne yer verilmiştir.

Söz konusu hükümler idare ve mükellefler arasında ihtilaf düzeyine gelince, Gelir İdaresi Başkanlığı tarafından konuyla ilgili ihtilafların çözülmesi ve uygulamada birliğin sağlanması açısından 15.08.2011 tarihli Genel Yazı'da "Kanununun $6 \mathrm{ncı}$ maddesinin (c) fıkrasında, muris veya tasarrufu yapan şahsın Türkiye'de hiç ikamet etmediği veya son 
ikametgâhı tespit olunamadığı durumda veraset ve intikal vergisinin Maliye Bakanlığının tayin edeceği yer vergi dairesince tarh olunacağı hükme bağlanmıştır.

Mükelleflere kolaylık sağlanması bakımından, murisin Türkiye'deki ikametgâh adresinin bulunmaması veya tespit edilememesi halinde, tarha yetkili vergi dairesinin belirlenmesi için mükellefler tarafından Maliye Bakanlığı (Gelir Idaresi Başkanlığı)'na verilecek dilekçeler vergi dairesi başkanlıkları / defterdarlıklar veya vergi dairelerince kabul edilerek Başkanlığımıza intikal ettirilecektir. Başkanlığımızca da ilgili vergi dairesi başkanlıkları / defterdarlıklar yetkili kılınmak suretiyle bunlar tarafından tarha yetkili vergi dairesi belirlenecektir" hükümlerine yer verilmiştir.

Yine, Gelir İdaresi Başkanlığı tarafından 30.12.2013 tarihinde yayımladığı Veraset ve İntikal Vergisi 45 Nolu Genel Tebliğ'de, "Muris veya Tasarrufu Yapan Şahsın ikametgâhı Tespit Olunamaması Durumunda Beyannamenin Verileceği Yer Vergi Dairesi,

7338 sayılı Kanunun 6 ncı maddesinin (c) fıkrasında, muris veya tasarrufu yapan şahsın Türkiye'de hiç ikamet etmediği veya son ikametgâhı tespit olunamadığı takdirde veraset ve intikal vergisinin Maliye Bakanlığının tayin edeceği yer vergi dairesince tarh olunacağı; 8 inci maddesinin birinci fıkrasında da, beyannamelerin 6 ncı maddenin (c) fıkrasına giren hallerde Maliye Bakanlığına verileceği hükme bağlanmıştır.

213 sayılı Vergi Usul Kanununun 4 üncü maddesinin ikinci fıkrasında ise; "Mükelleflerin, vergi uygulaması bakımından hangi vergi dairesine bağlı oldukları vergi kanunları ile belirlenir. Ancak, Maliye ve Gümrük Bakanlığı, gerekli gördüğü hallerde, mükelleflerin işyeri ve ikametgâh adresleri ile il ve ilçelerin idarî sınırlarına bağlı kalmaksızın vergi daireleri ve bölge bilgi işlem merkezleri kurmaya, vergi dairelerine bağlı şubeler açmaya ve vergi dairelerinin yetki alanı ile vergi türleri, meslek ve iş grupları itibariyle mükelleflerin bağlı olacakları vergi dairesini belirlemeye yetkilidir." hükmü yer almaktadır. Bu madde hükmünün Bakanlığımıza verdiği yetki uyarınca, muris veya tasarrufu yapan şahsın Türkiye'de hiç ikamet etmediği veya son ikametgâhı tespit olunamadığı takdirde veraset ve intikal vergisi beyannamelerinin, veraset yoluyla veya sair surette ivazsız tarzda intikal eden malın bulunduğu veya mükelleflerin ikametgâhlarının bağlı olduğu yer vergi dairesine verilmesi uygun görülmüştür" hükümlerine yer verilmiştir.

Dikkat edildiğinde zaten vergi karmaşıkığının zirvesinde ve işlem maliyetlerinin yüksek olduğu kanunda, yayımlanan tebliğle daha da karmaşık hale gelmiştir. Şöyle ki, müteveffanın birçok ilde malvarlığı olduğunu ve yaşam koşullarının ülkenin dört bir yanına dağıttığı varislerin görevlerini yerine getirmedeki zorluk derecesinin yanı sıra teknoloji darboğazımızın göstergesi olarak E-VDO uygulamasının izin vermemesi işlemleri daha da karmaşık hale getirmiştir. Örneğin, Muris, Şanlıurfa'da doktorluk / öğretmenlik vb. yaparken aldığı arsasını, tayin sebebiyle gittiği yerlerde (Gaziantep ve Kahramanmaraş gibi illerde) elde ettiği kıymetlerinin, Antalya Manavgat'ta vefat ettiği ancak bir türlü resmi olarak ikametgahının tespit edilememesi esnasında, ayrıca varislerinin de memleketin dört bir yanına dağıldığını göz önüne aldığımızda, mükelleflerin bir yakınlarını kaybetmiş olmasının verdiği elem ve bir an önce intikal eden kıymetlerin tasarrufu imkanına kavuşma arzusu nedeniyle hiç gündeme getirilmemektedir. 
Vergi mükelleflerinin devlet karşısındaki hakları(mükellef hakları) en az yükümlülükleri (ödevleri) kadar önemlidir (Egeli \& Dağ, 2012: 132). Somutlaştırmak gerekirse; sistem, artan oranlı bir tarifeye sahip olan kanuna ilişkin verilecek beyannamenin, ilk hangi vergi dairesine verilirse işlemin orada devam ettirilmesi gerektiğini belirtmektedir. Malların bulunduğu yer vergi dairesi- mallar birçok yerde varsa, veyahut mükelleflerin bulunduğu yer vergi dairesi-birçok mükellef bulunmaktaysa, matrahın tek havuzda toplatılmak istenmesi ve teknolojik altyapının cevap verememesi sorunları hayli arttırmaktadır. Dolayısıyla, tesis edilen idari işlemleri gerçekleştirecek teknolojik altyapının kurulması önem arz ediyor.

ViVK. 9. maddesinde: "Beyannameler aşağıda yazılı müddetlerde verilir:

1. Veraset tarikiyle vukuu bulan intikallerde;

a) Ölüm Türkiye'de vukuu bulmuş ise mükelleflerin Türkiye'de bulunmaları halinde ölüm tarihini takip eden dört ay içinde, mükelleflerin yabancı bir memlekette bulunmaları halinde ölüm tarihini takip eden altı ay içinde;

b) Ölüm yabancı bir memlekette vukuu bulmuş ise mükelleflerin Türkiye'de bulunmaları halinde ölüm tarihini takip eden altı ay içinde, mükellefler müteveffanın bulunduğu memlekette oldukları takdirde ölüm tarihini takip eden dört ay içinde, mükellefler müteveffanın bulunduğu yerin dışında başka bir yabancı memlekette oldukları takdirde de ölüm tarihini takip eden sekiz ay içinde; bir ay içinde;

c) Gaiplik halinde, gaiplik kararının ölüm siciline kaydolunduğu tarihi takip eden

2. Diğer suretle vaki intikallerde malların hukuken iktisap edildiği tarihi takip eden bir ay içinde.

3. Gerçek veya tüzel kişilerce düzenlenen yarışma ve çekilişler ile 5602 sayılı Kanunda tanımlanan şans oyunlarında, yarışma ve çekiliş ile müsabakaların yapıldığı günü takip eden ayın 20. günü akşamına kadar" hükmüne yer verilmektedir. Beyanname verilme müddeti aşağıdaki tabloda yer almaktadır.

Tablo 2: Beyanname Verilme Müddeti ve Ödeme

\begin{tabular}{|c|c|c|c|c|c|}
\hline \multirow{5}{*}{$\begin{array}{l}\text { Veraset ve } \\
\text { Intikal Vergisi } \\
\text { Beyannamesi }\end{array}$} & \multirow[t]{5}{*}{$\begin{array}{l}\text { Veraset Yoluyla } \\
\text { Meydana Gelen } \\
\text { İntikallerde }\end{array}$} & \multirow{2}{*}{$\begin{array}{l}\text { 1-Ölüm } \\
\text { Türkiye'de } \\
\text { Meydana } \\
\text { Gelmişse }\end{array}$} & $\begin{array}{l}\text { Varislerin } \\
\text { Türkiye'de Bulunma } \\
\text { Hali }\end{array}$ & $4 \mathrm{Ay}$ & \multirow{5}{*}{$\begin{array}{l}\text { Tahakkukundan } \\
\text { itibaren üç yılda } \\
\text { her yıl mayıs ve } \\
\text { kasım aylarında } \\
\text { olmak üzere altı } \\
\text { eşit taksitte } \\
\text { ödenir. }\end{array}$} \\
\hline & & & $\begin{array}{l}\text { Yabancı Bir Ülkede } \\
\text { Bulunma Hali }\end{array}$ & $6 \mathrm{Ay}$ & \\
\hline & & \multirow{3}{*}{$\begin{array}{l}\text { 2-Ölüm } \\
\text { Yabancı } \\
\text { Ülkede } \\
\text { Meydana } \\
\text { Gelmişse }\end{array}$} & $\begin{array}{l}\text { Varislerin } \\
\text { Türkiye'de Bulunma } \\
\text { Hali }\end{array}$ & $6 \mathrm{Ay}$ & \\
\hline & & & $\begin{array}{l}\text { Varislerin Murisin } \\
\text { Bulunduğu Ülkede } \\
\text { Bulunması Hali }\end{array}$ & $4 \mathrm{Ay}$ & \\
\hline & & & $\begin{array}{l}\text { Varislerin Murisin } \\
\text { Bulunduğu Ülkeden } \\
\text { Başka Bir Ülkede } \\
\text { Bulunması Hali }\end{array}$ & $8 \mathrm{Ay}$ & \\
\hline
\end{tabular}




\begin{tabular}{|c|c|c|c|c|c|}
\hline \multirow{3}{*}{$\begin{array}{l}\text { Veraset ve } \\
\text { Intikal Vergisi } \\
\text { Beyannamesi }\end{array}$} & & $\begin{array}{l}\text { 3-Gaiplik } \\
\text { Halinde }\end{array}$ & $\begin{array}{l}\text { Gaiplik Kararının } \\
\text { Ölüm Siciline } \\
\text { Kaydolduğu Tarihi } \\
\text { İzleyen }\end{array}$ & $1 \mathrm{Ay}$ & \\
\hline & $\begin{array}{l}\text { İvazsız } \\
\text { İntikallerde }\end{array}$ & \multicolumn{2}{|c|}{$\begin{array}{l}\text { Malların Hukuken İktisap Edildiği } \\
\text { Tarihi İzleyen }\end{array}$} & $1 \mathrm{Ay}$ & \\
\hline & $\begin{array}{l}\text { Gerçek veya } \\
\text { tüzel kişilerce } \\
\text { düzenlenen } \\
\text { yarışma ve } \\
\text { çekilişler ile } \\
5602 \text { sayılı } \\
\text { Kanun }\end{array}$ & \multicolumn{2}{|c|}{$\begin{array}{l}\text { Gerçek veya tüzel kişilerce } \\
\text { düzenlenen yarışma ve çekilişler } \\
\text { ile } 5602 \text { sayılı Kanunda } \\
\text { tanımlanan şans oyunlarında, } \\
\text { yarışma ve çekiliş ile } \\
\text { müsabakaların }\end{array}$} & $\begin{array}{l}\text { Yapıldığı } \\
\text { günü } \\
\text { takip } \\
\text { eden ayın } \\
\text { 20. günü } \\
\text { akşamına } \\
\text { kadar. }\end{array}$ & $\begin{array}{l}\text { Beyanname } \\
\text { Verilme süresi } \\
\text { içinde ödenir. }\end{array}$ \\
\hline
\end{tabular}

Kaynak: 7338 sayılı Veraset ve İntikal Vergisi Kanunu'nun 9. ve 19. maddesi göz önünde bulundurularak tarafımca hazırlanmıştır.

Medeni Kanun'un 610'uncu maddesine göre, "Yasal süre içinde mirası reddetmeyen mirasçı, mirası kayıtsız şartsız kazanmış olur" denilmektedir. Bilindiği üzere beyanname verilme süresinin ölüm tarihinden itibaren olması diğer taraftan Medeni Kanun'un 606. maddesinde: "Miras, üç ay içinde reddolunabilir. Bu süre, yasal mirasçılar için mirasçı olduklarını daha sonra öğrendikleri ispat edilmedikçe mirasbırakanın ölümünü öğrendikleri; vasiyetname ile atanmış mirasçılar için mirasbırakanın tasarrufunun kendilerine resmen bildirildiği tarihten işlemeye başlar" hükümlerinde ölümün öğrenildiği tarihin esas alınması, hükümlerin çelişmezliği ilkesine gölge düşürdüğü apaçık ortadadır.

Miras bırakandan kendisine değeri 200.000 TL olan 2 adet gayrimenkul kaldığını öğrenen mirasçı, aynı miras bırakanının çeşitli bankalara 3.00.000 TL borcu olduğunu öğrendiğinde terekenin aktifinin pasifini karşılamaması nedeniyle genellikle mirası reddetme hakkını kullanmakta böylelikle miras bırakanından kalan 200.000TL değerindeki gayrimenkulleri alamasa da 300.000TL'lik banka borcundan da sorumlu olmamaktadır. Mirası reddetme hakkını ölümün üzerinden yıllar geçmiş olsa bile ölümü öğrendiği tarihten itibaren 3 ay içinde kullanıp banka borçlarından kurtulabilirken, ölüm tarihinden itibaren 4 ay içinde veraset ve intikal beyannamesi vermediği için çeşitli cezalar ödemek zorunda kalmakta, bu durum ise hiçbir gelir elde etmediği bir mirasa ilişkin olarak beyanname vermediği için usulsüzlük ve vergi ziyaı cezası ödemek zorunda kalmak gibi hakkaniyete aykırı bir duruma yol açmaktadır (Ersan, http://www.ersanoz.com/kose-yazilari/07-25-2013-mirascilar-dikkat.pdf, Mayıs, 2017).

Ayrıca Vergi Usul Kanunu'nun 342. maddesi gereğince ek süreler hakkında, "Veraset ve intikal vergisine ilişkin mükellefiyetlerde tahakkuk muamelesi yapılmak için beyanname verme süresinin sonundan başlayarak 15 gün beklenir. Beyanname bu süre içinde verilirse vergi ziyaı olmamış sayılır. Ayrıca mükellefe tebliğ edilmek şartı ile yeniden 15 günlük bir mühlet verilir. Bu hususta da yukarıdaki hüküm cari olur" hükmü yer almaktadır. Dikkat edildiğinde usul yönünden tebliğ edilme hususunun alakasızık ve göz ardı edilmesi müteakip hükümlerin uygulanabilirliğini zayıflatmaktadır. 
Idari tetkik ve tahkikatın yetersizliği nedeniyle esnek olan cezai müeyyidelere ek olarak doğacak olan vergilerden mahrum kalınmaktadır. Şöyle ki; Vergi Daireleri İşlem Yönergesinde, "Adresi tespit edilen mükellefler adına, veraset ve intikal vergisi beyannamelerini süresinde vermeyenlere ait "BEYANA ÇAĞRI MEKTUBU" iki nüsha olarak düzenlenir. Adresi tespit edilemeyen mükellefler hakkında gerekli araştırmalar yapılır" denilmektedir. Dolayısıyla tahsis edilecek yeterli sayıda muktedir personel tarafından gerçekleştirecek bu işlemler, vergi ve cezai müeyyidelere yasal dayanak oluşturacaktır. Mükellefin beyana davet edilmesi neticesinde davete icabet edilmemesi durumunda 213 sayılı Vergi Usul Kanunu'nun 342. maddesi ve iç Genelgeleri doğrultusunda vergi ziyaı cezası müeyyidesini uygulama imkanı getirmektedir. Mükellefin beyana davet edilmesi yıllar sonra kesilecek vergi ziyaı cezasına yasal dayanak oluşturup mükellefler üzerinde caydırıc bir tesiri olacaktır. Ancak uygulamada yargı kararları da göz önünde bulundurulduğunda usulsüzlük cezaları ile yetinilmektedir.

Insani bir müessese olan, idare ve mükellefi birbirine yakınlaştıran pişmanlık ve Islah müessesine ilişkin VUK 371. maddesinde: "Beyana dayanan vergilerde vergi ziyaı cezasını gerektiren fiilleri işleyen mükelleflerle bunların işlenişine iştirak eden diğer kişilerin kanuna aykırı hareketlerini ilgili makamlara kendiliğinden dilekçe ile haber vermesi hâlinde, haklarında aşağıda yazılı kayıt ve şartlarla vergi ziyaı cezası kesilmez.

1. Mükellefin keyfiyeti haber verdiği tarihten önce bir muhbir tarafından her hangi resmi bir makama dilekçe ile veya şifahi beyanı tutanakla tevsik edilmek suretiyle haber verilen husus hakkında ihbarda bulunulmamış olması (Dilekçe veya tutanağın resmi kayıtlara geçirilmiş olması şarttır.)

2. Haber verme dilekçesinin yetkili memurlar tarafından mükellef nezdinde her hangi bir vergi incelemesine başlandığı veya olayın takdir komisyonuna intikal ettirildiği günden evvel (Kaçakçılık suçu teşkil eden fiillerin işlendiğinin tespitinden önce) verilmiş ve resmi kayıtlara geçirilmiş olması.

3. Hiç verilmemiş olan vergi beyannamelerinin mükellefin haber verme dilekçesinin verildiği tarihten başlayarak onbeş gün içinde tevdi olunması.

4. Eksik veya yanlış yapılan vergi beyanının mükellefin keyfiyeti haber verme tarihinden başlayarak onbeş gün içinde tamamlanması veya düzeltilmesi.

5. Mükellefçe haber verilen ve ödeme süresi geçmiş bulunan vergilerin, ödemenin geciktiği her ay ve kesri için, 6183 sayılı Kanunun 51 inci maddesinde belirtilen nispette uygulanacak gecikme zammı oranında bir zamla birlikte haber verme tarihinden başlayarak onbeş gün içinde ödenmesi.

Bu madde hükümleri, emlak vergisi ile ilgili olarak uygulanmaz" hükmü yer almaktadır.

Her ne kadar VUK 371. maddenin son hükmünde pişmanlık ve ıslah hükümlerinin, emlak vergisine uygulanamayacağı mefhumunun muhalifinden ve yargı kararlarında da söz konusu müessesenin mutlak anlamda uygulanabileceği belirtilse de spesifik olarak ilgili kanunun özel hükümleri dikkate alındığında teoride ve pratikte olanaksızdır. Ve bu hükmün şartları ve manasının amacı vergi ziyaı cezasının önlenmesinden başka bir şey değildir. 2000/1 seri nolu iç genelgede de belirtildiği 
üzere mükellefe tebliğ edilmek şartıyla ikinci 15 günlük bir süre verilir. Bu sürede beyanın verilmesi halinde de vergi ziyaı olmamış sayılır. Yine mükellefin beyanını süresinde vermiş olmasına rağmen bir kısım mallarını beyan dışı bıraktığının idarece tespiti sonucunda idare mükellefe tebliğ edilmek şartıyla ikinci 15 günlük süre verir. Mükellef bu süre içinde de beyanname verirse vergi ziyaı olmamış sayılacaktır.

Ancak idarenin vermiş olduğu ikinci 15 günlük sürelerde beyan verilmemesi halinde bu süreden sonra verilecek beyanlarda vergi ziyaı oluşacaktır. Her ne kadar bu müessesenin amacı, beyana dayanan vergilerde vergi ziyaı cezasının kesilmesinin belli şartlar dahilinde önlenmesi ise de bu durumda da pişmanlık hükümlerinden yararlanılması söz konusu olmayacaktır. Dikkat edilirse, bu hususta vergi ziyaı cezasını gerektiren fiil oluşmasına rağmen pişmanlık müessesesi uygulanamamaktadır. Çünkü bu durumda mükellefin beyanname vermediği veya beyanname vermekle birlikte bazı malları beyan dışı bıraktığı vergi dairesince tespit edilmiş ve mükellefe bildirilmiş olduğundan, pişmanlık hükümlerinden yararlanılması mümkün olmayacaktır. Sadece, beyan edilen intikale konu malların değerlerinin arttırılmasına ilişkin olarak pişmanlık talebi ile verilen beyannameler kabul edilebilir.

Bilindiği üzere; 2007/1 sayılı İç Genelge'de; Veraset Ve İntikal Vergisi Beyannamesi'nin kanunda öngörülen süreden sonra verilmesi nedeniyle uygulanacak usulsüzlük cezasının, söz konusu beyannamenin verildiği tarihte uygulanmakta olan usulsüzlük cezalarına ilişkin tutarlar esas alınarak, her bir mirasçı için ayrı ayrı kesilmektedir. Örneğin; vefat tarihi 11.11.2011 olan bir mükellefin beyannamesi 31.12.2016 tarihinde verildiğinde, uygulanan cezai müeyyide fiilin işlendiği tarih olarak 2016 yılındaki usulsüzlük cezasıdır. Demek ki fiil, beyannamenin verildiği tarihte işlenmiş sayılıyor ki suç unsurlarının temelini idari tahkikattaki noksanlıklar oluşturmaktadır. Yine, her ek beyanda diğer vergi türlerinden farklı olarak, mükellefe cezai müeyyide uygulanmaktadır. Diğer taraftan, verginin gecikmeli de olsa tahsili, tahsilat gelirlerinin artması bakımından önem taşımaktadır.

Değerleme; 213 sayılı Vergi Usul Kanunu'nda vergi matrahlarının hesaplanmasıyla ilgili iktisadi kıymetlerin takdir ve tespiti olarak tanımlanmaktadır.

ViVK. 11. maddesinde, Değerleme gününe ilişkin olarak: "Bu vergiye mevzu olacak malların değerleme günü miras yoluyla vuku bulan intikallerde mirasın açıldığı, diğer suretle vaki intikallerde malların hukuken iktisap edildiği, gündür" hükmü yer almaktadır. Değerleme yapılırken çok düşük olarak hesaplanan vergi değerleri matrahı aşındırmaktadır. Bu değerlerin doğru saptanabilmesi için etkin denetim mekanizmaları devreye sokulmalı ve hesap verilebilirlik, Takdir Komisyonları'nın yetki- sorumlulukları arttırılmalıdır. Vergi değeri yerine rayiç değer baz alınmalıdır. Medeni Kanun 575. Maddesinde mirasın açılması ve değerleme anı, bir başka ifadeyle mirasçıların mirasa hak kazanmasına ilişkin olarak "Miras, mirasbırakanın ölümüyle açılır. Mirasbırakanın sağlığında yapmış olduğu mirasla ilgili kazandırmalar ve paylaştırmalar, terekenin ölüm anındaki durumuna göre değerlendirilir" hükmü yer almaktadır.

Dolayısıyla, beyannamede malların ölümün vukuu bulduğu gün itibariyle oluşan değerleri gösterilmektedir. Bu durum, özellikle geç beyan veren mükellefler açısından 
önemli avantajlar sağlayabilmekte ancak; bu husus kayıtdışılığı beraberinde getirmektedir.

Hayatın olağan akışına ve ticari teamüllere bakıldığında her metanın kural olarak değerinin yükseldiği yönünde bir realite vardır. Burada dikkat etmek gerekir ki; varis (mükellef) 1985 yılında vefat eden murisin (müteveffa) beyannamesini 2017 yılında vermiş olsa dahi kanun lafzından da anlaşılacağı üzere; tarhiyatın temelinde 1985 yılındaki vergi değeri vardır. Veraset ve İntikal Vergisi'ndeki farklı ceza uygulamaları dikkate alındığında, intikali hukuki muameleye bağlı olan birtakım tereke unsurları olmadıkça mükelleflerin beyana yanaşmaması ve geç beyandan ötürü ağır şekilde cezalandırılmamaları söz konusudur. Değerleme gününün ölüm tarihinin esas alınarak tespit edilmesi, bu geç beyanda bulunulmuş kişiler açısından daha da avantajlı bir durum yaratmakta, böylelikle mükellefler adeta geç beyanda bulunmaya teşvik edilmiş olur (Maç \& Jamali 1999: 309). Geç verilen beyannamelerde elde edilecek vergi ve türev gelirler Olivera-Tanzi etkisine maruz kalmaktadır. Taşınmaz değerlemesi ile ilgili kamuoyu ve yerel yönetimlerin karşı karşıya getirilmemesi için çıkarılacak bir kanun ile özel sektörden yararlanma yoluna gidilebilir (Tarin, 2013: 166).

ViVK. 12. maddesinde: "iktisabedilen malların değerlerinden veya değerleri yekûnundan aşağıda yazılı borçlar ve masraflar, beyannamede gösterilmek şartıyla tenzil olunur.

a) Veraset yoluyla vukubulan intikallerde murisin ihticaca salih vesaika müstenit borçları ile vergi borçları;

b) Diğer suretle iktisaplarda intikal eden malın aynına taalluk eden borçlarla vergi borçları (Şu kadar ki, hibe eden hibe ettiği mala taalluk eden borçları kendi üzerine almış veya öyle taahhüt etmiş ise bu borçlar nazara alınmaz);

c) Türkiye Cumhuriyeti tabiiyetinde olan şahıslara ait mallardan yabancı memleketlerde bulunanlara taalluk eden borçlar ve yabancı memleketlerde bu mallar dolayısıyla alınan Veraset ve intikal vergileri (Tevsik edilmek şartıyla);

c) Fıkrasında yazılı borçlar ile Veraset ve intikal vergileri, beyannamede gösterilen bu kabil malların değerini geçemez.)

d) Cenazenin teçhiz ve tedfini için yapılan masraflar" tenzil olunabilecek borçlar ve masraflar olarak belirtilmektedir.

Burada dikkat edilmesi gereken hususlardan bir tanesi de, yapılan düzenlemeyle mükerrer bir vergilemenin önüne geçilmiş değildir. Çünkü yurtdışında ödenen veraset ve intikal vergileri ödenip tevsik edilmesi şartıyla ödenecek vergiden değil matrahtan düşüleceği hususu mükerrer vergilemeyi önlemekten çok uzak bir uygulama olduğu kesindir. Küreselleşme çağını yaşadığımız göz önüne alındığında sadece kendi mevzuatımızı değil diğer ülke mevzuatlarını da göz önünde bulundurmamız gerekmektedir. Küreselleşme ve uluslararası birleşmeler artık ülkelerin kendi başlarına tam bağımsız maliye politikaları uygulamalarını ve özellikle bu alanın en duyarlı ögesini oluşturan vergi sistemlerini çok büyük ölçüde yönlendirmekte, hatta kısıtlamaktadır (Özdemir, 2009: 2). 
Vergi tarifeleri, devlet-ekonomi organik ilişkisinin temelidir. Yani devlet iktisadi hayata müdahalede bulunmak istediğinde, ilk işi tarifeler üzerinden ekonomik ajanların davranışlarını etkileyerek bunu gerçekleştirebilir.

Modern veraset vergisi, iki yönlü artan oranlı bir tarifeye sahip olduğu söylenebilir. Çünkü, artan oranlılık bir yandan veraset yoluyla intikal eden mirasın tutarını, diğer yandan ölen ile mirasçı veya lehine vasiyet edilen kimse ya da bağış yapan ile yapılan arasındaki akrabalık derecesine göre düzenlenir.

ViVK. 16. maddesinde: "Veraset ve Intikal Vergisi aşağıda yazılı nispetler üzerinden alınır. Verginin tarifesi aşağıdaki tabloda yer almaktadır.

Tablo 3: Vergi Tarifesi

\begin{tabular}{|c|c|c|}
\hline Matrah & $\begin{array}{l}\text { Veraset Yoluyla } \\
\text { İtikallerde (\%) }\end{array}$ & $\begin{array}{l}\text { İvazsız İntikallerde (\%) (Ana Baba Eş ve } \\
\text { Çocuklarda Yarısı düşük uygulanır) }\end{array}$ \\
\hline $210.000 \mathrm{TL}$ & 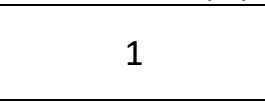 & (5 \\
\hline $\begin{array}{l}\text { Sonra gelen } \\
\text { için }\end{array}$ & 3 & $15-7,5$ \\
\hline $\begin{array}{l}\text { Sonra gelen } \\
\text { için }\end{array}$ & 5 & $20-10$ \\
\hline $\begin{array}{l}\text { Sonra gelen } 2.000 .000 \mathrm{TL} \\
\text { için }\end{array}$ & 7 & $25-12,5$ \\
\hline $\begin{array}{l}\text { Matrahın } 3.820 .000 \text { TL'yi } \\
\text { aşan bölümü için }\end{array}$ & 10 & $30-15$ \\
\hline
\end{tabular}

Kaynak: 2017 Yılı 48 Numaralı Veraset ve İntikal Vergisi Genel Tebliği göz önünde bulundurularak tarafımca hazırlanmıştır.

Bir şahsa ana, baba, eş ve çocuklarından (evlatıktan evlat edinenlere yapılan ivazsız intikaller hariç) ivazsız mal intikali halinde vergi, ivazsı intikallere ilişkin tarifede yer alan oranların yarısı uygulanarak hesaplanır. Vergi tarifesinin matrah dilim tutarları, her yıl bir önceki yıla ilişkin olarak Vergi Usul Kanunu uyarınca belirlenen yeniden değerleme oranında artırılmak suretiyle uygulanır. Bu şekilde hesaplanan dilim tutarlarının \%5'ini aşmayan kesirler dikkate alınmaz. Bakanlar Kurulu, bu suretle tespit edilen tutarları yarısına kadar artırmaya veya indirmeye yetkilidir. 5602 sayılı Kanunda tanımlanan şans oyunları ile gerçek ve tüzel kişilerce düzenlenen yarışma ve çekilişlerde kazanılan ikramiyelerde oran \%10 olarak uygulanır. ikramiyenin ayni olarak ödenmesi halinde, fatura değeri esas alınır." denilmektedir. Ödeme gücü zayıf olanlar lehine yükseklik ve uzunluk oranları dönüştürülmelidir. İki bağımsız olayda matrahların farklı olması ve akrabalık derecelerinin de göz önünde bulundurulduğu bir tarife oluşturulmalıdır.

Örneğin; 2017 yılında vefat eden kişinin 800.000 TL miras bıraktığı(Gayrimenkul, menkul, hak, ...), geriye bir eşi ve iki çocuğu kaldığı varsayıldığında, eşe ve her çocuğa isabet eden ve miras payından $177,600 \mathrm{TL}$ istisna düşüldükten sonra kalan tutar Veraset ve İntikal Vergisi matrahı kabul edilip tarife uygulanacaktır. 
Eş (1/4) 200.000-177.600=22.400\%1=224 TL

1. Çocuk $300.000-177.600=122.400 \% 1=1.224 \mathrm{TL}$

2. Çocuk $300.000-177.600=122.400 \% 1=1.224 \mathrm{TL}$

(Mükellefler, tahakkuk eden vergiyi üç yıl içinde mayıs ve kasım aylarında ikişer eşit taksit halinde ödeyip tasdiknamesini alacaktır.)

Medeni Kanun'unun 495. ve müteakip maddelerde (495-501); sağ kalan eş, miras bırakanın altsoyu (Birinci zümre hısımlar) ile birlikte mirasçı olursa, mirasın dörtte biri, miras bırakanın ana babasıyla (ikinci zümre hısımlar) birlikte mirasçı olursa, mirasın yarısına, miras bırakanın büyük ana büyük babaları ve onların çocukları (Üçüncü zümre hısımlar) ile birlikte mirasçı olursa, mirasın dörtte üçü bunlar da yoksa mirasın tamamına hak kazanır. Mirasçı bırakmaksızın ölen kimsenin mirasının Devlet'e geçeceği belirtilmektedir.

1959 yılında TBMM'de Veraset ve İntikal Vergisi kabul edildiğinde, yürürlükteki Medeni Kanun'da "Mal Ayrılığı” yasal mal rejimi olarak düzenlenmişti. Bu nedenle Veraset ve İntikal Vergisi mal ayrılığı rejimi dikkate alınarak hazırlanmıştır. Medeni Kanunumuzun değişmesi ile Veraset ve İntikal Vergisi Kanunu'nda yer alan düzenlemelerin gözden geçirilmesi gereği doğmuştur (Ortaç, 2002: 214).

Medeni Kanun'unun 219. maddesinde: “Edinilmiş mal, her eşin bu mal rejiminin devamı süresince karşılığını vererek elde ettiği malvarlığı değerleridir. Bir eşin edinilmiş malları özellikle şunlardır:

1. Çalışmasının karşılığı olan edinimler,

2. Sosyal güvenlik veya sosyal yardım kurum ve kuruluşlarının veya personele yardım amacı ile kurulan sandık ve benzerlerinin yaptığı ödemeler,

3. Çalışma gücünün kaybı nedeniyle ödenen tazminatlar,

4. Kişisel mallarının gelirleri,

5. Edinilmiş malların yerine geçen değerler " hükmü yer almaktadır.

Bu hususta 01.01.2002 sonrası ölümlerde yasal mal rejimi-edinilmiş mallara katılım çerçevesinde eşe düşen miktar ayrıldıktan ya da istisna kapsamına alındıktan sonra geriye kalan kısım için yukarıdaki hükümler doğrultusunda taksimi gerekmektedir.

Bilindiği üzere ödeme gücü yaklaşımında artan oranlı tarifenin önemi büyüktür. Herkesin ödeme gücünü göz önüne alırken uzunluk ve yükseklik farkları, verimlilik esasına göre düzenlenmelidir. Örneğin İlk matrahların daha büyük olması ve ilk vergi oranlarının daha düşük olması takip eden dilimlerde bu oranların sıçrayışla yükselmesi hakkaniyete uygun olacağı kesindir. 1998 tarihine kadar ki tarifelere bakıldığında; evlatlık 1. ve 2. grup dışındakiler içinde yer almaktadır ve ana, baba ve kardeşlere uygulanan vergi oranları göz önünde bulundurulduğunda, daha adil bir tarife olduğu söylenebilir. 


\section{Vergiye Mukabil Teminat, Ödeme ve Kasa Muhteviyatının Tespiti}

Tevkifat yöntemi (kaynaktan kesme) ile vergi dairesi, beyannamelerin getirdiği iş yükünden ve mükelleflerin de beyanname verme külfetinden kurtarılmış olmaktadır. Kanun, kural olarak beyan usulüne istisnai hallerde tevkifat usulüne dayanmaktadır. Şöyle ki, ViVK. 17. maddesinde: "Amme idare ve müesseseleri, bankalar, bankerler, kasa kiralayanlar, sigorta şirketleri, sair şirket ve müesseseler, mahkemeler ve icra daireleri istihkak sahiplerine bu verginin mevzuuna giren her hangi bir muamele dolayısıyla para ve senet verebilmek için evvelemirde verginin ödenmiş olduğuna dair vergi dairesinden verilmiş bir tasdikname talep ederler. Tasdikname ibraz etmeyen hak sahiplerinin istihkaklarından, veraset yoluyla intikallerde \%5, ivazsız intikallerde \%15 oranında vergi karşılığı olarak tevkifat yaptıktan sonra, bakiyesini verebilirler. Tevfikatı yapanlar, tevkif ettikleri parayı en geç bir hafta içinde bulundukları yerin mal sandığına yatırmaya ve keyfiyeti bağlı bulundukları vergi dairesine yazı ile bildirmeye mecburdurlar. Tevkifat yapmadan para ve senet verenlerle tevkif ettikleri parayı yukarıda belirtilen süre içinde mal sandığına yatırmayanlardan (Hakimler hariç), tevkif etmeye ve yatırmaya mecbur oldukları paralar Amme Alacaklarının Tahsil Usulü hakkında Kanun hükümlerine göre gecikme zammı tatbik edilerek tahsil edilir. Tevkifatı yapan ilgili kuruluşların, bu görevleri süresinde yerine getirmeyen sorumlularından, tevkif etmeye ve yatırmaya mecbur oldukları paraların \%10'u oranında ayrıca ceza tahsil olunur" hükmü yer almaktadır.

Idarenin işlemlerine esas olmak üzere, Vergi Daireleri İşlem Yönergesi'nin teminatın mahsup ve iadesi ile ilgili işlemlere ilişkin hükümlerine bakıldığında; "Kuruluş ve müesseseler, tasdikname ibraz etmeyen hak sahiplerinin istihkaklarından tevkifat yapmak, yaptıkları tevkifatı en geç bir hafta içinde en yakın vergi dairesine yatırmak ve durumu ilgili vergi dairesine bir yazı ile bildirmek zorundadırlar. Yapılan tevkifata ilişkin yazının veya bu konuda Muhasebe Kayıt Servisinden gönderilen servis notunun alınması üzerine; veraset ve intikal vergisi olay kayıt ve hesap defterine gerekli kayıtlar yapılır ve buna ilişkin yazı veya servis notu işlem dosyasına konulur. Bu işlemler üzerine herhangi bir bordro düzenlenmez. Vergiye karşılık tevkif edilen ve ilgili kurum veya kuruluş̧̧a vergi dairesine yatırıldıktan sonra emanet hesabına alınan teminatın her mirasçının ödemesi gereken verginin birinci taksitinden başlayarak Muhasebe Kayıt Servisinden tamamen mahsup edilmesi istenir" denilmektedir.

Tevkifat yöntemi, tasdikname ibraz etmeyen mükelleflerden yapılan kesintileri ilgili mal sandıklarına aktarmaya yönelik hükümdür. Kaynaktan kesme suretiyle mükellef ve idare arasında herhangi bir sürtüşmeye meydan vermeden gerçekleştiğinden basit ve mükellef odaklı bir hizmettir. Tevkif edilen tutarlar, mükelleflerin genel hükümlere göre verecekleri beyannameler üzerinden hesaplanan vergilerden mahsup edilir (Şenyüz vd. 2016: 380). Dikkat edildiğinde, idareler arası ve idarenin bizzat kendi içerisinde işlem karmaşıklığının basit idari işlemle sadeleştirilmesi bir an önce gerekmektedir. Yani düzeltme işlemlerine hacet kalmaksızın nihai bir vergileme ile son bulmalıdır.

Vergi Daireleri İşlem Yönergesi'ne göre; veraset yoluyla intikal eden mal istisna haddinin altında kalsa dahi beyanname verilmesi gerekmekte iken, ivazsız intikallerde ise istisna haddi altında kalanlar için beyanname verilmez. 28 Seri No'lu Veraset Ve 
Intikal Vergisi Kanunu Genel Tebliği'nde; "Yarışma ve çekilişlerde kazananlara verilen ikramiyelerin değerinin istisna haddinin altında kalması halinde, bu tutar üzerinden yarışma ve çekilişi düzenleyenlerce vergi tevkif edilmeyecek ve beyanname verilmeyecektir. Ayrıca, bu tür ikramiye kazananların kazandıkları bu ikramiyeler nedeniyle beyanname vermeyecekleri tabidir" denilmektedir.

34 Seri No'lu Veraset ve İntikal Vergisi Kanunu Genel Tebliği'nde; “... at yarışları üzerine düzenlenen müşterek bahislere katılanlar, kazandıkları ikramiyenin istisna tutarını aşması halinde, bu tutarı hukuken iktisap ettikleri tarihten itibaren bir ay içinde ikametgahlarının bağlı olduğu yer vergi dairesine beyan etmekte ve beyan üzerine tahakkuk eden veraset ve intikal vergisini de 3 yılda, her yıl Mayıs ve Kasım aylarında olmak üzere toplam altı eşit taksitte ödemekteydiler.

4783 sayılı Kanunun 11 inci maddesi ile Veraset ve Intikal Vergisi Kanununun 7, 9, 16 ve 19 uncu maddelerinde 01/02/2003 tarihinden geçerli olmak üzere bazı ibare değişiklikleri yapılmıştır. Anılan maddelerde yapılan değişikliklere göre, at yarışları üzerine müşterek bahis düzenleyenlerin, 01/02/2003 tarihinden (bu tarih dahil) itibaren düzenleyecekleri müşterek bahisler sonucunda ödenecek ikramiyelerin istisna tutarını (4) aşması halinde, ikramiyelerin istisna tutarını aşan kısmı üzerinden \% 10 oranında vergi kesmeleri gerekmektedir.

Diğer taraftan, Veraset ve intikal Vergisi Kanununun 16 ncı maddesinde yapılan ibare değişikliği ile yarışma ve çekiliş düzenleyen gerçek ve tüzel kişiler tarafından düzenlenen yarışma ve çekilişlere ilişkin ikramiyeler ile futbol müsabakaları üzerine düzenlenen müşterek bahislere ilişkin ikramiyeler üzerinden \% 20 olarak kesilmekte olan vergi oranı \% 10 olarak değiştirilmiş bulunmaktadır. Bu durumda, 01/02/2003 tarihinden itibaren düzenlenen yarışma ve çekilişler ile futbol müsabakaları üzerine düzenlenen müşterek bahisler sonucunda ödenecek ikramiyenin istisna tutarını așan kısmı üzerinden de \% 10 oranında vergi kesilecektir. Öte yandan, 01/02/2003 tarihinden itibaren düzenlenen at yarıșlarına ait müssterek bahislerden ikramiye kazananlar da, yarıșma ve çekiliște ikramiye kazananlar ile futbol müsabakaları üzerine düzenlenen müsterek bahislerden ikramiye kazananlarda olduğu gibi, kazandıkları bu ikramiyeler nedeniyle beyanname vermeyeceklerdir" hükümleri idarenin işlemlerine esas olup işlem karmaşıklığı bir nebze de olsa önlenmek istenmiştir.

ViVK. 19. maddesinde: "Veraset ve intikal vergisi tahakkukundan itibaren (3) yılda ve her yıl Mayıs ve Kasım aylarında olmak üzere iki eşit taksitte (gerçek ve tüzel kişilerce düzenlenen yarışma ve çekilişlerde kazananlara ödenecek ikramiyeler ile 5602 sayılı Kanunda tanımlanan şans oyunları dolayısıyla dağıtılacak ikramiyelerden kesilen vergiler beyanname verme süresi içinde) ödenir. Tescil tarihinden itibaren en geç 15 gün içinde sonucu ilgili vergi dairesine bildirilmek üzere, intikal eden gayrimenkullerin tescil işlemi, veraset ve intikal vergisinin tahakkuku beklenmeksizin yapılır. Ancak, intikali yapılan gayrimenkule isabet eden veraset ve intikal vergisi tamamen ödenmedikçe devir ve ferağı yapılamaz ve üzerinde herhangi bir ayni hak tesis edilemez. Tapu memurları vergi dairesince verilmiş ilişik kesme belgesi olmaksızın devir ve ferağ işlemi yapamazlar, aksi halde verginin ödenmesinden mükellefler ile birlikte müteselsilen sorumlu olurlar. Ancak, mükelleflerce, tahakkuk eden vergiye karşılık 6183 sayılı Kanunun 10. maddesinde yazılı cinsten (Bu maddenin 5. bendinde yazılı menkul 
mallar hariç) teminat gösterildiği takdirde intikal eden gayrimenkullerin bir kısmının veya tamamının devir ve ferağına izin verilebilir. Teminat olarak gösterilecek gayrimenkullerin değeri 6183 sayılı Kanunun 90. maddesinde yazılı komisyonlar tarafından aynı Kanunun 91. maddesine göre tespit edilir" denilmektedir.

Tescil işleminin tahakkuk beklenmeksizin yapılması Emlak Vergisi'nde mükellefiyeti ve tarhiyat sırasında matrahın temelindeki emlak vergi değerlerinde karışıklığa yol açmaktadır. Kaosun ortadan kaldırılması için ehli vukuf tescil kurulları oluşturulmalıdır. Verginin 3 yıl içinde ödenebilmesine izin veren hüküm, tasdiknameyi de verginin tamamen ödemesine bağlayarak mülkiyet hakkında hemen tasarrufta bulunmak isteyen mükelleflerde reaksiyona yol açmaktadır. Anlaşılması zor olan bu alan mükellef odaklı hizmet anlayışından hareketle yeniden düzenlenmelidir. Çıkan vergi mükellefin ödeme gücü göz önünde bulundurularak maksimum bir yıl içinde iki eşit takside indirgeyerek sadelik sağlanmalıdır.

ViVK. 23. maddesinde: "Bankalar nezdindeki kiralık kasa sahiplerinden birinin ölümü halinde (Sulh hakimi tarafından yapılacak tespit hariç) vergi dairesinin salahiyetli bir memuru hazır bulunmadıkça kasanın açılmasına ve bu memur huzurunda tespit edilmedikçe muhteviyatının mirasçıları veya kanuni temsilcileri veya vekilleri tarafından alınmasına müsaade edemezler" denilmektedir. Bu husus şüphesiz güven ve beyan esasını zedelemektedir. Ödenecek verginin doğruluğunun teminine halel gelmeyecek şekilde zinhar ağır cezai müeyyidelerin uygulanacağı hususu belirtilip, sorumluluk banka personeline aktarılıp iletişim çağının gereklerine uyulmalıdır.

\section{Kanun'un Varlığını Savunanlar, Eleştirenler ve Mükellef Rantı}

Veraset ve Intikal Vergisi'nin varlığını savunan ve eleştiren taraflar bulunmaktadır. Servet vergilerinin varlı̆̆ını sakıncalı olarak görenlere bakıldığında; teorik olarak çifte vergilemeye mahal vermesi, mülkiyet hakkına müdahaleye neden olması ve servetin yoğunlaşmasına sebep verip iktisadi hayata menfi tezahür edeceği söylenilmektedir. Asıl amacını, vergilendirme sürecinin uzun olmasından dolayı, gerçekleştiremediğinden ve konjonktürü terbiye edecek bir mecrası ve marifeti bulunamadığından ve işlem maliyetlerinin yüksek ayrıca kırtasiyeciliğin fazla olmasından dolayı kaldırılması gerektiği düşünülmektedir.

Servet vergilerini savunanların ileri sürdükleri en önemli iddialar, servet vergilerinin uygulanmasının kolay ve gerçek gücü gösteren servet üzerinden alındığı için adalete uygun olduğudur (Şafak, 2013: 6). Vergilemede adalet ilkesinin bel kemiğidir. Türkiye'de servet vergilerinin uygulamadan kaldırılması bozuk olan gelir ve servet dağılımının daha da bozulmasına ve servetlerin belirli kesimlerde toplanmasına yol açabilecektir. Her ne kadar bugün uygulanan servet vergileriyle bu amaca ulaşmak söz konusu olamasa da yapılacak düzenlemelerle servet dağılımı iyileştirilebilir. Bu nedenle servet vergilerinin uygulanmasına son vermek sosyal açıdan da büyük sakıncalar doğuracaktır (Heper, 1982: 136).

Tasarrufların artırılmasına yönelik olarak şans oyunları, yarışma ve çekilişlerde kazanılan ikramiyeler üzerinden artan oranlı veraset ve intikal vergisi alınma seçeneği 
değerlendirilmelidir (Kalkınma Bakanlığı, Özel Vergi İhtisas Komisyon Raporu 20142018: 54). Veraset ve intikal vergisini haklı görenlerin ve bütçedeki payının rehabilite edilmesi gerektiğini düşünenlere göre; miras veya bağış yoluyla servet edinilmesi esnasında çekilen bir zahmetten söz etmek mümkün değildir. Yapılan bir çalışmada, bazı Avrupa Birliği üyesi ülkelerin Veraset ve İntikal Vergisi sistemleri incelenmiş ve söz konusu verginin tarihsel geçmişi ile toplam vergi hasılatı içindeki payı arasında pozitif bir ilişki tespit edilmiştir (Aydın, 2009: 65-66). Yani incelenen ülkelerde Veraset ve Intikal Vergisi ne kadar eskiye dayanıyorsa Veraset ve İntikal Vergisinin toplam vergi gelirleri içindeki payı da o kadar yükselmektedir. Türkiye'de Veraset ve İntikal Vergisi 1926 yılından itibaren uygulana gelmiş ve bu süreçte tek kapsamlı denilebilecek değişiklik 1959 yılında çıkarılan yeni kanunla yapılmıştır. Günümüz koşullarında kanunun uygulanmasında ortaya çıkan sorunların giderilmesi ve etkin hale getirilmesi için yeni bir düzenlemeye gitmek kaçınılmaz görünmektedir. Bu şekilde zaman içerisinde hasılata da yansıyacak iyileşmelerin olması beklenebilir (Kılıçaslan, 2011: 344). Bu verginin diğer vergilere nazaran daha kolay kabul edilebilmesinin başlıca sebebinin de olduğu söylenebilir. Miras, eşit kabiliyetlerin eşit şartları için işe başlamalarını engelleyerek kişinin diğerlerine üstünlük kurmasını sağlar (Kükrer, 1987: 25). Servetlerin vergilendirilmeyip intikali, bu servetlerin hepsinin aynı kişilerin kontrolünde kalmaya devam etmesine, toplumu etkileyen bir tarafı bulunmamaktadır. Servetin tek elde bulunması sermayenin tek elde birikmesinin önünde duracaktır. Söz konusu vergi sağken bireylerin vergiden kaçındıkları alanların vergilemesi tamamlayıcı bir etki doğurmaktadır. Gelir ve harcama üzerinden alınamayan vergileri tamamlayan bir vergi olması açısından önem arz eder. Örneğin; bir serbest meslek erbabının Gelir Vergisi Kanunu kapsamında bilanço makyajları ve beyannamelere takla attırılması, yaptığı giderlerin şişirilmesi ve matrahının aşınması sonucu alınamayan vergileri aslında sadece ve sadece servet vergileri ile tamamlanmış olur.

Servet, mali güç ölçütü olduğundan hareketle gelir ve servet arasındaki dengeyi sağlayan, devletin de mirasın külfetine hizmet eden taraf olarak paydaşlığı bu tamamlayıcı ve sosyal politika aracı olarak kullanılabilecek verginin bütçe içerisinde hak ettiği değeri bulması asıl meseledir. Gereken önem verildiğinde müdahale aracı dahi olabilir kudretli politika aracı vasfına mazhar olabilir. Küreselleşen dünyada gelir ve harcama üzerinden alınan vergilerin payının düştüğü ve toplumların sosyal ilerleme isteklerinin ve savunma amaçlı güvenlik tedbirlerinin yol açtığı kamu harcamalarının artışı bu hususun ne kadar önem kazandığını ortaya çıkarmaktadır. Devletin bu servetin korunmasında ve güvenli bir şekilde kullanılmasındaki vazifesi sonucu nimetten de istifade edebilmesi tabiidir. En önemlisi de varsıl ve yoksul kesimin ortak paydası ve aralarındaki zımni bir mukavelenamedir.

Maliye politikasının önemli araçlarından olan bütçe; hukuki, sosyal, iktisadi, mali ve siyasi yönünden fonksiyonları bulunan bir uygulamadır (Akdoğan, 2014: 334). Bütçenin, iktisadi ve mali fonksiyonu kıt kaynakların en etkin biçimde kullanılması ve devletin giderleri için alternatif gelir kaynakları bulması anlamına gelmektedir (Bülbül, 2014: 29). Medeniyet geliştikçe intiyaçlar çeşitleniyor ve derinleşiyor. Toplumların sosyal iktisadi ve teknik olarak gelişme istekleri kamu harcamalarını arttırmaktadır. Artan kamu harcamalarının finanse edilebilmesi ve milli cüzdanın denkleştirilmesi maharet haline geliyor. Her ne kadar toplumsal beklenti ve kamu kesiminin 
fonksiyonları artış gösterse de söz konusu taleplerin yerine getirilmesi için kullanılacak kaynaklardaki artışın aynı şekilde olmaması ve ayrıca vergi idaresinin kamu hizmetlerini finanse etmek için vergileri artırma yeteneklerinin sınırlı olması gerek dünyada gerekse ülkemizde kamu harcamalarının etkinlik ve verimlilik kavramları çerçevesinde değerlendirilmesini gerekli kılmaktadır (Aysu \& Bakırtaş, 2016: 83). Devlete olan güven duygusunu geliştiren işleyiş karşısında vatandaşlarda da vergiye ve devlete karşı pozitif bilinç oluşur (Öz, 2004: 1-40).

Mükellefin, önemli bir istisna olmakla birlikte her nasılsa ödemeye ilişkin sergilediği yaklaşımı bu vergide pozitiftir. Türkiye'de örneklem olarak seçilen yıllar bazında Veraset ve İntikal Vergisi tahmin ve gerçekleşmelerinden hareketle bütçe içerisindeki payının yükseltilebileceği sonucuna ulaşılmıştır. Veraset ve İntikal Vergisi'ne ilişkin tahmin ve göstergeler aşağıdaki tabloda yer almaktadır.

Tablo 4: Bütçe Göstergeleri

\begin{tabular}{|c|c|c|c|}
\hline Yıllar & Bütçe Tahmini(Milyon) & Gerçekleşme(Milyon) & Gerçekleşme Oranı \\
\hline 2009 & 122.548 .000 & 168.253 .000 & 137,70 \\
\hline 2010 & 156.019 .000 & 215.462 .000 & 137,80 \\
\hline 2011 & 217.943 .000 & 253.014 .000 & 116,60 \\
\hline 2012 & 288.717 .000 & 292.682 .000 & 100,10 \\
\hline 2013 & 231.653 .000 & 339.799 .000 & 146,75 \\
\hline 2014 & 399.565 .000 & 428.244 .000 & 107,20 \\
\hline 2015 & 450.000 .000 & 435.253 .000 & 96,00 \\
\hline 2016 & 489.0000 .000 & 619.000 .000 & 126,58 \\
\hline
\end{tabular}

Kaynak: Bütçe Ve Mali Kontrol Genel Müdürlüğü Verileri Baz Alınarak Tarafımca Hazırlanmıştır.

Nasıl ki her türküde bir hikâye varsa paradigmalarda veyahut retoriklerde olsun bir yaşanmışlık vardır. Söz gelimi idarenin kapısına ayak basan mükellefin gözlerindeki yaş ve sonrasındaki sevinç terminolojik olarak mükellef rantının temellerini atmıştır denilebilir. Bu bağlamda mükellef rantı; Mükellefin ödemeyi düşündüğü vergi ile hesaplanan vergi(ödediği veya ödeyeceği vergi) arasındaki fark olup temelindeki hususlar şöyledir;

-Bir an önce mülkiyet sahibi olma,

-Zenginliğin verdiği etkiyle psikolojik olarak kabul ettiği vergi sınırının yüksek olması,

-Tasarrufta bulunmak isteği,

-Önceden düşündüğü projeleri gerçekleştirme arzusu ... olarak belirtilebilir. Yani ödevli sorumluluğunu yerine getirirken daha yüksek miktarda ödeyeceği vergi cüzi miktarda çıktığında elem etkisi tebessüme daha da ötesi gülüşmelere kadar gitmektedir. Aslında bu gösterge dahi kanunun boşluğuna karine teşkil etmektedir. 


\section{Sonuç ve Değerlendirme}

Nimet külfet taksimatı, maliye tarihinden ders alınarak yapılırsa; hiç şüphesiz mali anlamda tarih tekerrür etmeyecektir. Bu idrak temelinde devletin makro ve mikro görevlerini yerine getirirken, adalet ve objektiflik ilkeleri ekseninde hukuk sistematiği içerisinde hareket etmesi, vatandaşların ise; devlet idaresine karşı güven ve uyum çerçevesinde hareket etmesi çok büyük önem taşımaktadır. Devlet aygıtının paternalistik ve alturistik "baba devlet-diğergam" bir rol alabilmesi için kamu gelirleri içinde en büyük öneme sahip vergi gelirlerine ve adil bir vergi yükünün temini için sosyal politika aracı olabilecek servet vergileri büyük öneme sahiptir. Servet, mali güç ölçütü olduğundan hareketle üzerinden alınan vergilerle, gelir ve servet arasındaki dengeyi sağlayan bir mekanizmadır. Ödeme gücü göstergelerinden servetin vergi dışı bırakılması Anayasa'nın amir hükümlerine ve vergilemede adalet ilkesine aykırılık teşkil etmektedir. Bu hususta iktisadi hayatta nasıl ki tam istihdama ulaşmaya çalışırken her bir üretim faktörünün değeri yadsınamıyorsa, başarılı bir vergileme politikasının temelinde de vergilerin ekstra fiskal yani ekonomik ve sosyal fonksiyonları göz ardı edilmemelidir. Yoksul ve varsıl kesimin gelirlerinin ve servetlerinin dağılımında adaletin temini için devletin kıymetli bir politika aracı olduğu unutulmamalıdır. Rasyonel vergileme ilkeleri doğrultusunda kamu gelirlerini çevreleyen yasal bir mekanizma temelinde, devletin de mirasın külfetine hizmet eden taraf olarak paydaşlığı, bu tamamlayıcı ve sosyal politika aracını kullanabilmesi ve söz konusu verginin bütçe içerisinde hak ettiği değeri bulması ası meseledir.

Mali gücün göstergesi olan servetin vergi dışı bırakılması, bir ebeveynin muzip çocuğuna söz geçiremeyip uslu çocukları olan gelir ve harcamaya kızması gibi bir şeydir. Türkiye' de Veraset ve İntikal Vergisi'nin anayasal dayanağı olarak "sosyal devlet" ilkesi ve sonrasında yine Anayasa'nın 73/1. maddesinde geçen "herkesin mali gücüne göre vergilendirilmesi" ibaresidir. Vergi gelirleri içerisinde düşük bir paya sahip olan Veraset ve İntikal Vergisi'nin, neden hala uygulanmakta olduğunun cevabı ise; servetin de bir ödeme gücü unsuru olmasının yanı sıra, vergilemede adaletin tesisi ve gelirin yeniden dağılımını sağlayan önemli bir sacayağıdır.

Uygulamada birliğin sağlanması açısından kanun metninin doyurucu ve açık bir şekilde gözden geçirilmesi gerekmektedir. Özellikle idarenin işlemlerine yön veren Vergi Daireleri iş̧lem Yönergesi ve E-VDO uygulamasının zaman kaybedilmeden tespit edilen hususlar doğrultusunda bir an önce dönüştürülmesi gereği önem arz eder. Bu alanda sosyal, teknolojik ve mali olgular göz önünde bulundurulmalıdır. Söz konusu vergiyi sosyal ve mali amacından saptıran nedenlerin başında, geniş belirlenen istisnalar, idari tahkikattaki aksaklıklar ve mali istihbaratın yeterince geliştirilememesi sonucu tespitlerin gecikmesi gibi faktörler gelmektedir. Kanundan, idari tahkikatın noksanlığından ve teknolojik imkânsızlıktan, hazineye geç intikal eden kaynakların zaman değerinin göz ardı edilmesi, ikametgâhın tespit edilememesinden doğan bu ve benzeri aksaklıklar mali ve sosyal yönden bu kanunun başarılı bir kanun olmasını önlemektedir. Değişen ekonomik konjonktüre ve ticari teamüllere uygun, uygulamada birliğin sağlandığı, teoride ve pratikte diğer düzenleyici işlemlere duyarlı kurallar bütününü ihtiva eden kural ve kaidelerle bahse konu olan sorunlara çözüm önerileri ve temenniler etkinliği ve verimliliği arttıracaktır. Vergi sistemimiz basitleştirilerek gerek 
vergi idaresi gerekse toplum tarafından uygulanabilir ve kolay anlaşılır hale getirilmelidir. Vergi idaresi gelişen teknolojiyi daha yaygın ve etkin kullanarak kayıt dışı ekonomi ile mücadelede büyük başarılar sağlayabilir.

Veraset ve Intikal Vergisi'nde bazı sorunlar, mükelleflerin yakınlarını kaybetmiş olmasının verdiği üzüntü ve bir an önce intikal eden kıymetlerin tasarrufu imkânına kavuşma arzusu nedeniyle hiç gündeme getirilmemektedir. Aslında vergi politikalarının oluşumuna bakıldığında ekonomi yönetiminin en önemli araçlarından biri olup, iyi uygulanmadığı zaman vatandaşın devlete olan güvenini sarsarak kayıtdışılığı artırmaktadır. Böylece aslında devlet lehine davranıldığı için fazla yapıldığı düşünülen tahsilat, toplam vergi gelirlerini artırmak yerine azaltmaktadır. İdarenin, nasıl olsa mükellefler tarafından itiraz edilmeden kabul ediliyor düşüncesi ile yanlış uygulamalardan kaynaklanan sorunları devam ettirme yerine, bu sorunları çözme konusunda göstereceği başarı ile sağlayacağı zaman tasarruflarının iyi bir sosyal ve hukuk devleti olmak için gerekli vergi politikalarının geliştirilmesi ve uygulanması konusunda imkânları artıracağı kuşkusuzdur.

Kapsam açısından geniş olan bir konunun şahsilik prensibinin uygulanamaması ve mükellefin beyan vereceği idarenin tespiti sorunsalı açısından teknolojik altyapının geliştirilmesi, vergi oranlarının tekrar gözden geçirilmesi, sermaye birikimimizintasarruflarımızın baz alınarak istisna-muafiyetlerin regüle edilmesi, tahsilatta kolaylığa gidilmesi, varsıl kesimin vergiye bakışı, sınırsız bir zamanaşımının mükellefe ve idareye verdiği olumsuzluklar ... oluşturulacak yeni düzenlemelerde göz önüne alınarak, çözüme yönelik bahsedilen hususların nazarı dikkate alınması da önem arz eder. Civar hısımları ve edinilmiş mallar rejimi kapsamında eşe düşen kısım istisna kapsamına engelli varislerin iktisapları muafiyet kapsamına alınması sosyal devlet anlayışını daha da pekiştirecektir.

Değerleme konusunda gerçek değere yakın değerlerin elde edilebilmesi için sağlam bir veri tabanı oluşturulmalıdır. Değerleme gününün, beyannamenin verildiği gün olarak belirlenmesi hakkaniyete uygun olacağı söylenebilir. Vergi matrahının mükellef ve idarece ayrı ayrı tespit edilmesi (ilk ve son tarhiyat), vergiyi karmaşık bir hale getirdiğinden, idare ile mükellef malları değerlemede aynı değerleme ölçütlerini seçmeli ya da ortak tarhiyat için bir düzenleme yürürlüğe konmak suretiyle tarhiyat farklııklarının yol açtığı maliyet, emek ve zaman kaybı da önlenmiş olacaktır. İki başlı tarhiyat kaosunun kaldırılarak tek tarhiyat halinde basite indirgendiğinde mükellef ve idare arasındaki değerleme kıstası mükellef odaklı bir anlayış temelinde geliştirilebilir.

Sağlam mali istihbarat, idari tahkikat ve tetkiklerle tesis edilen idari işlemler neticesinde vergilendirme sürecinin basite indirgenerek mükellef odaklı hizmet anlayışla vergi idareleri açısından hissedilebilir derecede verimliliğin sağlanacağı siyah ve beyazın farklılığı gibi kesindir. Devir işlemlerinde karışıklığa yol açmaması açısından tescil işlemleri koordinasyon kurulları aracılığıyla yapılmalıdır. Vergi karmaşıklığının temelindeki işlem maliyetlerinin mutlak surette azaltılarak mükelleflere devletin vakarını, itibarını ve kendi yükümlülüklerini hatırlatacak caydırıcı cezaların ihdas edilmesi, teknolojik darboğazların aşılması önem arz etmektedir. 
Her ne kadar kural olarak beyan esasına dayalı çözümler öne sürülmüş olsa da kaynaktan artan oranlı bir vergileme sistemi temelinde, ilgili kurumlar vergiyi kaynaktan tevkif ederek vergi dairelerine parasal olarak aktarması, hem vergi dairelerinin hem de vergi mükelleflerinin reaksiyonlarının temelindeki; verginin tahsili için harcadıkları emek, vergi uzmanlarına başvurarak ödedikleri ücretler, zaman kaybının önlenmesinin yanı sıra, kayıt dışılığı da azaltacaktır.

Ödeme sürelerinde, hesaplanan vergilere ve mükellefin ödeme gücü göz önünde bulundurularak taksitlendirme yoluna gidilip mükellefin üç yıl nihayetinde tasdiknameden (iliş̧ik Belgesi) mahrum bırakma yolu terk edilmelidir. Şöyle ki; idare hem üç yıl süre içinde ödeme imkânı veriyor hem de sürenin hitamından sonra mükellefe tasdiknameyi vermektedir. Oysa mükellef hemen malını satıp planlarındaki tasarruflarını gerçekleştirmek istediğinde verginin hepsini ödemek zorunda kalmaktadır.

Kurumlar arası bilgi akışının zayıf olması tespitlerin gecikmesine neden olurken bu husus hazineye vergilerin gecikmeli olarak intikal etmesine yol açmaktadır. Vergi karmaşıklığını önlemek ve idarenin vergi ve feri alacaklarına yasal dayanak oluşturmak adına Vergi Usul Kanunu'ndaki ek süreler kaldırılmalıdır. Vergi dairelerinde ilgili masaya yetkin ve yeterli sayıda personel tahsisi ve kasa muhteviyatının tespitinde teknolojik imkânlardan yararlanılması sisteme güven aşılayacak olup emek ve zaman kaybını önleyecek ve bürokrasiyi azaltacaktır. Pişmanlık ve Islah hükümlerinin mutlak anlamda uygulanabildiği bir mevzuat sistemi de oluşturularak mükelleflerin kendiliğinden beyanda bulunulması sağlanmalıdır. Psikolojik olarak benimsenmiş bir verginin rehabilite edilmesiyle istenilen sonuçlara ulaşılacağı muhakkaktır.

Kaldırılması tartışma konusu olan verginin yukarıda belirtilen sorunlara getirilen çözüm önerileri ve arz edilen temenniler kümülatif olarak nazar-ı dikkate alındığında, normatif değerler ekseninde memleketin 81 vilayetinde tesis edilen idari işlemler sağlıklı hale gelecek olup zerre-i miskal ihtilafa mahal ve müphem bir mesele kalmayacak ve en önemlisi Veraset ve İntikal Vergisi, Merkezi Yönetim Bütçe Gelirleri içinde önemli bir kamu geliri olarak yer alacaktır. Güçlü bir teori (mevzuat) ve pratik (uygulamada birlik) temelinde servet temelli vergi gelirlerinde bir sıçrayış gerçekleşecektir.

Ülkeler tarafından, dünyanın ekonomik, mali, hukuki, sosyal ve siyasal eğilimleri göz önünde bulundurulduğunda, mutlak surette kayıtsı kabul yerine menfaatlere uygun ve dayatma olmaksızın özgül sistemler oluşturulabilir. Aslında bu hususların artık kaçınılmaz olduğu da kabul edilebilir. Çünkü politikaların belirlenmesinde etili olan ve artık birçok ekonomik örgüt tarafından, özellikle -WB, IMF, G7, G8, G20- gibi her yapıya uygulanmak üzere mali reçeteler verildiği görülmektedir.

Türkiye'de olduğu gibi ABD'de de 2003 yılında verginin kaldırılması tartışılsa da toplumunun sosyal dokularını iyi özümsemiş olmalılar ki, varsıl kesim karşı çıkmıştır. Finans cambazı olan George Soros: " Zenginlerle fakirler arasındaki uçurum giderek açılıyor, bu sağlıksız bir gelişme ve miras üzerindeki vergi kalkarsa, bu uçurum daha da büyür. Vergi ölüm gibi tatsız ve bir gerçek, ikisinden de kaçamazsınız. Ama veraset vergisi daha zararsız, hiç olmazsa zenginlik yaratılmasına engel değil..." (Şafak, 2013: 
106). Evet. Aslında ne mülkiyeti kısıtlar ne de tam manasıyla buradan gelecek vergilerle tozpembe bir mali hayat olur. Ancak toplumda sosyal barışın temel dinamiklerinden bir parça olarak görülebilir.

Gelir dağılımındaki dengesizliklerin temelinde servet dağıımındaki dengesizliklerin büyük etkisi vardır. Ekonomik kalkınmanın temelindeki vergileme ve harcama politikaları oluşturulurken, vergi ve harcama bilinçlerini göz ardı edilmeden, özellikle de gelir dağılımında adaletin gerçekleştirilmesinde, Max Otto Lorenz'in bükülen eğrisini dikleştirmek aynı zamanda Cornado Gini'nin katsayısını sıfıra yakınlaştırmanın temelinde, toplumu ayrıştıran değil katılımcılığa önem veren ve topluma hizmet eden uygulamalar mutlak surette göz önünde bulundurulmalıdır. Söz konusu hususlar dikkate alındığında mali gücün servet sacayağı sağlamlaşacak olup varsıl ve yoksul kesim arasındaki köprü yenilenecektir.

Vergiler, çağdaş medeniyetlerin göz bebeği ve kalkınmanın temelidir. 


\section{Kaynakça}

Akdoğan, A. (2011). Kamu Maliyesi, 14. Baskı, Ankara, Gazi Kitabevi.

Bilici, N. (2014). Türk Vergi Sistemi, 33. Baskı, Ankara, Savaş Yayınevi.

Bülbül, D. (2014). Bütçe, Ankara, Gazi Kitabevi.

Ebu Yusuf, İ., Kitabü'l Haraç, (1973)(Çev. Ali ÖZEK- İstanbul Üniversitesi İktisat Fakültesi Maliye Enstitüsü Uzmanı). İstanbul, Hisar Yayınevi.

Edizdoğan, N. (2007), Kamu Bütçesi, 6.Baskı, Bursa, Ekin Kitabevi.

Egeli, H. Dağ, M.(2012). "Türk vergi hukuku açısından mükellef haklarının değerlendirilmesi", Maliye Dergisi.

Erdem M., Şenyüz D., Tatlıoğlu i. (2016). Kamu Maliyesi, Bursa, Ekin Kitabevi.

Falay, N. ( 1989). Maliye Ders Notları, Filiz Yayınevi.

Gönül, M. (2007). Veraset ve Intikal Vergisinde Istisnalar ile Tarifenin Oransal Yapı Açısından Değerlendirilmesi ve Analizi, (Yüksek Lisans Tezi), Ankara.

Heper F. (1982). Türkiye'de Servetlerin Vergilendirilmesi, Eskişehir, Eskişehir Iktisadi ve Ticari ilimler Akademisi Yayınları No:246/166.

Kaldor, N. (1981). "Türk Vergi Sistemi Üzerine Rapor", Toplum ve Bilim.

Kalkınma Bakanlığı. (2014). 10. Kalkınma Planı, Vergi Özel ihtisas Komisyonu Raporu, Ankara.

Karabacak, Y. (2004). Vergileme Politikaları Oluşumu Üzerine Bir Çözümleme Çerçevesi ve Türkiye, Doktora Tezi, İstanbul.

Karabacak, Y. (2012) "Sosyal Politika Aracı Olarak Vergilemenin Işlevleri: Türkiye Örnegi", istanbul Üniversitesi iktisat Fakültesi Mecmuası.

Karabacak, Y. (2013). "Vergi Karmaşıklığı Modern Vergi Sistemlerinin Kaçınılmaz Sonu mudur?", Mali Çözüm.

Kılıçaslan, H. (2011). "Veraset Vergisini Kaldırmak: Kayıtdışı Bir Ekonomi Bağlamında Bir Değerlendirme Ve Yeni Bir Düzenleme Önerisi", Maliye Dergisi.

Kükrer, S. (1987). Türk Vergi Sisteminde Servet Intikallerinin Vergilendirilmesi, Eskişehir Anadolu Üniversitesi Basımevi.

Maç, M. \& Jamali T. (1999). Veraset Hibe ve Ölüm, Denet, İstanbul.

Ortaç, F. R. (2002). "Yeni Yasal Mal Rejimi ve Veraset ve İntikal Vergisi”, G.Ü. iïBF Dergisi.

Önal Y., A., Temelli S. Der. (2012). Küresel Dönemde Vergileme, İstanbul.

Öz, E. (2004). Vergilendirmede Kanunilik ve Türk Vergi Sistemi, Buca, Gazi Kitabevi.

Öz, E. (2017). "Ölüm Vakalarının Türkiye'de Vergisel Açıdan Doğurduğu Hukuki Sonuçlar", Judicial Results Endengered by Death Cases in Turkey from A Taxaitional Perspective, Denizli.

Özbek, A. (2017). "Değerleme Ölçüsü Farklılığından Doğan Veraset ve İntikal Vergisi Tarhiyatında Gecikme Faizi Hesaplanabilir Mi?", Vergi Sorunları Dergisi. 
Özdemir, B. (2009). "Vergi Sistemlerinde Dolaysız Vergilerden Dolaylı Vergilere Kayış ya da Tüketim Vergilerinin Artan Ağırlı̆ı", Maliye Dergisi.

Özzeybek, M. (1976). Veraset Ve Intikal Vergisi Uygulama Yorum ve Açıklama, İstanbul, Eko Matbaa.

Piketty, T. (2004). 21. YY.da Kapital, Çeviren: Hande KOÇAK.

Saraçoğlu, F. (2009). "1930-1939 Döneminde Vergi Politikası", Maliye Dergisi.

Şafak H. (2015). "Yurtsever Hatice, Servet Vergilerinden Veraset ve İntikal Vergisi Üzerine Değerlendirmeler", Ege Akademik Bakış.

Şafak, H. (2013). Veraset ve Intikal Vergisi Ve Türk Vergi Sistemi Içerisindeki Yeri, Yüksek Lisans Tezi, Manisa.

Şenyüz, D., Yüce, M. \& Gerçek A. (2016). Türk Vergi Sistemi, 13. Baskı, Bursa, Ekin Basım Yayın Dağıtım.

Takım, A. (2011). “Türkiye'de 1960-1980 Yılları Arasında Uygulanan Kalkınma Planlarında Maliye Politikaları", Maliye Dergisi.

Tarin, E, (2013). Yerel Yönetimlerde Emlak Vergisinin Matrahının Tespiti, Karşılaşılan Sorunlar Ve Çözüm Önerileri, Yüksek Lisans Tezi, İstanbul.

Yereli, A. B. \& Uçar, O. (2014). "Türk Vergi Sistemi'nde Veraset ve Intikal Vergisi Uygulaması", Vergi Jurnalı.

Yeşilyurt, Ş. (2015). “Imam Ebu Yusuf'un Kamu Maliyesi Alanına Katkısı”, Maliye Dergisi.

Yılmaz, R. (1997). Ana Çizgileriyle Veraset ve Intikal Vergisi Ve Matrahın Tespiti, Yüksek Lisans Tezi, İstanbul.

2709 sayılı T.C. Anayasası

1319 sayılı Emlak Vergisi Kanunu (ilgili Tüzük ve Tebliğ)

213 sayılı Vergi Usul Kanunu

3670 sayılı Milli Piyango Teşkiline Dair Kanun

4721 sayılı Medeni Kanun

6183 sayılı Amme Alacakları Tahsil Usulü Hakkında Kanun

7338 sayılı Veraset ve İntikal Vergisi Kanunu

178 sayılı Kanun Hükmünde Kararname

04.05.2000 Tarih ve B.07.0.GEL.0.60/6000-2206/21253 sayılı Özelge

1 Seri No'lu Veraset Ve İntikal Vergisi Kanunu Genel Tebliği

1999/1 Seri Nolu Veraset Ve İntikal Vergisi Kanunu İç Genelgesi

2007/1 Seri Nolu Veraset Ve İntikal Vergisi Kanunu iç Genelgesi

22.05.2013 Tarih ve 9789501-160[1-2013/5-1.2.858]-759 sayılı Özelge

28 Seri No'lu Veraset Ve İntikal Vergisi Kanunu Genel Tebliği

34 Seri No'lu Veraset Ve İntikal Vergisi Kanunu Genel Tebliği

45 Seri No'lu Veraset Ve İntikal Vergisi Kanunu Genel Tebliği 
48 Seri No'lu Veraset Ve İntikal Vergisi Kanunu Genel Tebliği

Beyanname Düzenleme Klavuzu-2011

Maliye ve Sigorta Yorumları Yayınları

T.C. Resmi Gazete (18.03.1937 tarih ve 3557 sayı)

Vergi Daireleri İşlem Yönergesi

Vergi İnceleme ve Denetim İç Genelgesi

Vergi İncelemelerinde Uyulacak Usul Ve Esaslar Hakkında Yönetmelik

http://www.ersanoz.com/kose-yazilari/07-25-2013-mirascilar-dikkat_(03.03.2017)

www.gib.gov.tr (01.04.2017)

www.bumko.gov.tr (01.04.2017-01.08.2017)

www.tdk.gov.tr (01.04.2017) 